\title{
Estimating degree-day factors from MODIS for snowmelt runoff modeling
}

\author{
Z. H. He ${ }^{1}$, J. Parajka ${ }^{2}$, F. Q. Tian ${ }^{1}$, and G. Blöschl ${ }^{2}$ \\ ${ }^{1}$ State Key Laboratory of Hydroscience and Engineering, Department of Hydraulic Engineering, Tsinghua University, \\ Beijing, 100084, China \\ ${ }^{2}$ Institute for Hydraulic and Water Resources Engineering, Vienna University of Technology, Vienna, Austria \\ Correspondence to: F. Q. Tian (tianfq@ tsinghua.edu.cn)
}

Received: 11 July 2014 - Published in Hydrol. Earth Syst. Sci. Discuss.: 25 July 2014

Revised: 28 October 2014 - Accepted: 4 November 2014 - Published: 3 December 2014

\begin{abstract}
Degree-day factors are widely used to estimate snowmelt runoff in operational hydrological models. Usually, they are calibrated on observed runoff, and sometimes on satellite snow cover data. In this paper, we propose a new method for estimating the snowmelt degree-day factor $\left(\mathrm{DDF}_{\mathrm{S}}\right)$ directly from MODIS snow covered area (SCA) and ground-based snow depth data without calibration. Subcatchment snow volume is estimated by combining SCA and snow depths. Snow density is estimated to be the ratio between observed precipitation and changes in the snow volume for days with snow accumulation. Finally, $\mathrm{DDF}_{\mathrm{S}}$ values are estimated to be the ratio between changes in the snow water equivalent and difference between the daily temperature and the melt threshold value for days with snow melt. We compare simulations of basin runoff and snow cover patterns using spatially variable $\mathrm{DDF}_{S}$ estimated from snow data with those using spatially uniform $\mathrm{DDF}_{\mathrm{S}}$ calibrated on runoff. The runoff performances using estimated $\mathrm{DDF}_{\mathrm{S}}$ are slightly improved, and the simulated snow cover patterns are significantly more plausible. The new method may help reduce some of the runoff model parameter uncertainty by reducing the total number of calibration parameters. This method is applied to the Lienz catchment in East Tyrol, Austria, which covers an area of $1198 \mathrm{~km}^{2}$. Approximately $70 \%$ of the basin is covered by snow in the early spring season.
\end{abstract}

\section{Introduction}

Mountain watersheds serve as important water sources by providing fresh water for downstream human activities (Viviroli et al., 2003; Langston et al., 2011). As a result of snow and glacier melt, the magnitude and timing of runoff from these watersheds tend to be very sensitive to changes in the climate (Immerzeel et al., 2009; Jeelani et al., 2012). Changes of melt runoff may even affect the sustainable development of downstream cities in the long run (Verbunt et al., 2003; Zhang et al., 2012). Modeling snow and glacier melt runoff processes is therefore quite important for local water supply, hydropower management and flood forecasting (Klok et al., 2001). However, melt runoff modeling in such regions faces two challenges: scarcity of meteorological data and uncertainty in parameter calibration due to limited understanding of the complex hydrological processes.

Melt runoff models generally fall into two categories: energy balance models, and temperature-index models (Rango and Martinec, 1979; Howard, 1996; Kane et al., 1997; Singh et al., 2000; Fierz et al., 2003). Temperature-index models operating on a basin wide scale are much more popular for operational purposes due to the following four reasons (Hock, 2003): (1) wide availability of air temperature data, (2) relatively easy interpolation and forecasting possibilities of air temperature, (3) generally good model performance and (4) computational simplicity. The temperature index model is based on an assumed relationship between ablation and air temperature and calculates the daily snowmelt depth, $M\left(\mathrm{~mm} \mathrm{~d}^{-1}\right)$, by multiplying the difference between daily temperature and the melt threshold value, 
$T-T_{\mathrm{O}}\left({ }^{\circ} \mathrm{C} \mathrm{day}^{-1}\right)$, with the snowmelt degree-day factor, $\mathrm{DDF}_{\mathrm{S}}\left(\mathrm{mm}\right.$ day ${ }^{-1}{ }^{\circ} \mathrm{C}^{-1}$ ) (Howard, 1996). $T_{\mathrm{o}}$ is a threshold temperature for snowmelt. The temperature index model implies a consistent contribution of each of the heat balance components (including radiation, sensible heat, latent heat and ground heat fluxes). Any changes in climate conditions and the underlying basin characteristics will affect the relative contributions of the heat balance components and cause variations of the $\mathrm{DDF}_{\mathrm{S}}$ (Lang and Braun, 1990; Ohmura, 2001). The study of Kuusisto (1980) in Finland found DDF to increase sharply in early April, approximately doubling during this month due to increasing solar radiation. Singh and Kumar (1996) and Singh et al. (2000) demonstrated a seasonal decrease of $\mathrm{DDF}_{\mathrm{S}}$ with increasing albedo due to seasonal changes of land surface characteristics. Spatial variations of basin topography, such as elevation, terrain slope, aspect and terrain shading change the spatial energy conditions for snowmelt and lead to significant variations of $\mathrm{DDF}_{\mathrm{S}}$ (Marsh et al., 2012; Bormann et al., 2014). Generally, regions with a large contribution of sensible heat flux to the heat balance tend to have low degree-day factors (Hock, 2003). $\mathrm{DDF}_{\mathrm{S}}$ are expected to increase with increasing elevation and increasing snow density ( $\mathrm{Li}$ and Williams, 2008). Forest regions often have lower values of $\mathrm{DDF}_{\mathrm{S}}$ than open regions (Rango and Martinec, 1995). The identification of $\mathrm{DDF}_{\mathrm{S}}$ has been an important yet complex issue for the application of the temperature-index model for snowmelt runoff modeling.

Quite a few studies estimated the degree-day factor from observed snow water equivalent (SWE) data. Martinec (1960) measured SWE with radioactive cobalt and computed the $\mathrm{DDF}_{\mathrm{S}}$ as the ratio between SWE and difference between daily temperature and the melt threshold value. Rango and Martinec $(1979,1995)$ obtained degreeday factors from empirical regressions with snow density. Kane et al. (1997) estimated degree-day factors by calibration against point-measured SWE in a $2.2 \mathrm{~km}^{2}$ catchment. Daly et al. (2000) merged interpolated point-measured SWE with snow covered area derived from satellite data to obtain spatial snow water equivalent and estimated spatially distributed $\mathrm{DDF}_{\mathrm{S}}$ by calibration to spatial snow water equivalent. Bormann et al. $(2013,2014)$ coupled the method developed by Sturm et al. (2010) to estimate snow density as the ratio between point-measured SWE and snow depth data with the empirical relationship between $\mathrm{DDF}_{\mathrm{S}}$ and snow density of Rango and Martinec (1995) to estimate daily variable $\mathrm{DDF}_{\mathrm{S}}$. In these methods, detailed observations of snow water equivalent in the basin are needed. However, observations of snow water equivalent are only representative of a small subset of the spatial domain, and observations tend to be scarce at high elevations (Hamlet et al., 2005).

Another method of estimating the $\mathrm{DDF}_{\mathrm{S}}$ is treating it as a hydrologic model parameter and calibrating it on observed hydrological data. Most commonly, runoff is used for calibrating DDF (Hinzman and Kane, 1991; Klok et al., 2001; Luo et al., 2013). The drawback is that catchment runoff is not usually a good indicator of the spatial snow cover distribution (Blöschl et al., 1991a, b; Bach et al., 2003; Liu et al., 2012 etc.). Advances in remotely sensing techniques help provide more practical information for the calibration of $\mathrm{DDF}_{\mathrm{S}}$. There have been numerous comparisons between satellite snow cover products (e.g., Hall et al., 2000, 2002; Maurer et al., 2003; Lee et al., 2005; Hall and Riggs, 2007). In particular, MODIS snow covered area (SCA) products have been demonstrated to be of good quality and have been widely used in alpine hydrological modeling (Klein and Barnett, 2003; Dery et al., 2005; Andreadis and Lettenmaier, 2006; Wang et al., 2008; Georgievsky, 2009). Subsequently, a number of studies tested the potential of MODIS snow cover data for calibrating and validating snowmelt models (e.g., Dery et al., 2005; Tekeli et al., 2005; Udnaes et al., 2007; Parajka and Blöschl, 2008a). A review is provided by Parajka and Blöschl (2012). The authors generally found that including snow cover data in the model calibration improved the snow simulations. Most of these studies calibrated the $\mathrm{DDF}_{\mathrm{S}}$ on combined objective functions involving observed runoff and snow cover data. This makes it hard to obtain spatially variable $\mathrm{DDF}_{\mathrm{S}}$ because of the limited availability of spatially distributed runoff data. It is also important to note that the calibration of $\mathrm{DDF}_{\mathrm{S}}$ can be significantly affected by other model parameters due to the interdependency of the parameters and the nature of objective functions that reflect the joint effects of all the model parameters in a holistic way. The optimization procedures may there induce significant uncertainties in the parameter estimates (Kirchner, 2006), if insufficient attention is paid to the physical catchment characteristics (including elevation, vegetation coverage, and snow density etc.) affecting the value of $\mathrm{DDF}_{\mathrm{S}}$ (Bormann et al., 2014).

In mountain watersheds, distributed hydrologic models are more widely applied than lumped models due to the large spatial variability. Degree-day factors estimated from point measurements or spatially uniform values from calibration are not likely representative for the entire catchment. An increasing need for spatially distributed estimation of $\mathrm{DDF}_{\mathrm{S}}$ has been identified (Hock, 1999; Nester et al., 2011). However, only few studies have attempted to develop temperature-index methods in a distributed manner (Cazorzi and DallaFontana, 1996; Williams and Tarboton, 1999; Daly et al., 2000 etc.). Most of them computed the $\mathrm{DDF}_{S}$ as a function of radiation index, snow albedo, rainfall rate, elevation, snow density or wind speed, which are heavily affected by topography, thus addressing the spatial variability of snowmelt in mountain terrain (Dunn and Colohan, 1999; Hock, 2003). However, due to the complex interactions between atmospheric and surface characteristics affecting the degree-day factor, the relationship between $\mathrm{DDF}_{\mathrm{S}}$ and these characteristics is still not very well understood.

The objective of this study is to propose a new method for estimating spatial patterns of DDF from MODIS data in mountain catchments. In comparison to traditional methods, 
the $\mathrm{DDF}_{\mathrm{S}}$ is not calibrated to observed runoff and snow water equivalent data, but directly estimated from MODIS snow covered area and snow depth data alone. Snow depths can be more widely measured in the field than snow water equivalent. For example, Environment Canada gauges snow depth at 1556 sites, but snow water equivalent only at 27 sites. Similarly, the US Weather Service and the Swiss Service measure many more depths than water equivalents (Johnson and Schaefer, 2002; Zhou et al., 2005; Sturm et al., 2010). The new proposed method differs from existing estimation methods of $\mathrm{DDF}_{\mathrm{S}}$ in a number of ways: First, snow water equivalent is estimated from MODIS snow cover, snow depths and precipitation data, so there is no need for snow water equivalent measurements which are difficult to obtain in most mountain watersheds. Second, $\mathrm{DDF}_{\mathrm{S}}$ is estimated on a subcatchment scale rather than on a point scale as in most traditional estimation methods. Third, the study extends the idea of partitioning hydrological time series to explore hidden hydrological information of He et al. (2014) to the case of snow data. The methodology is tested in a mountain basin in Austria.

The remainder of this paper is organized in the following way: Sect. 2 details the estimation method of spatial snow density and the snowmelt degree-day factor, as well as the stepwise calibration method for the model parameters. Section 3 contains a description of the geographic and hydrological characteristics of the study basin, including the main data sources and data preprocessing. Section 4 presents the main simulation results and comparisons between the hydrologic model performance using $\mathrm{DDF}_{\mathrm{S}}$ estimated from snow data and $\mathrm{DDF}_{\mathrm{S}}$ calibrated on runoff. Finally, Sect. 5 provides a summary of the study, and discusses possible sources of uncertainty in the results and further applications of the new estimation methods of degree-day factors.

\section{Methodology}

The main idea of estimating the degree-day factor is as follows. The volume of snow for each subcatchment and each day is estimated using MODIS SCA data and ground-based snow depth time series. The snow volume time series are partitioned in time into three groups, based on the daily air temperatures: days with snow accumulation (when temperatures are below a threshold), days with ablation (when temperatures are above a different threshold) and days where both processes occur (when temperatures are between the thresholds). Snow density is estimated from the days with snow accumulation as the ratio between measured precipitation and changes in snow volume. The degree-day factor is estimated from the days with ablation as the ratio between measured changes in snow water equivalent (product of snow volume and density) and the difference between daily temperature and the threshold value.
For comparison, DDF $_{S}$ is calibrated on runoff using a semi-distributed hydrological model - THREW which has been applied in several studies (Tian et al., 2006, 2008, 2012; Mou et al., 2008; Li et al., 2012). The calibration follows the stepwise procedure developed by $\mathrm{He}$ et al. (2014) but was slightly modified because of the local characteristic of the study basin (see Sect. 2.2). The study basin is divided into 95 subcatchments for the simulations.

The estimated degree-day factors are tested by simulations of basin runoff and snow cover patterns. The study period for which the analyses are performed is 10 years, 2001-2010. 2001-2005 is the calibration period and 2006-2010 is the validation period.

\subsection{Estimation of degree-day factor from snow data}

The observed snow data used to estimate the degree-day factor, $\mathrm{DDF}_{\mathrm{S}}$, are snow covered area (SCA) products and ground-based snow depths. Firstly, we obtain the volume per area of snow in each subcatchment and for each day by $V_{\mathrm{s}}=\mathrm{SCA} \cdot D_{\mathrm{s}}$, where $D_{\mathrm{s}}$ is the average snow depth. Since the average snow depths tend to overestimate the snow covered area, therefore the multiplication with SCA is needed to compensate for the biases. In a next step, the change of snow water equivalent (SWE) between 2 days, $\frac{\mathrm{dSWE}}{\mathrm{d} t}=\rho_{\mathrm{S}} \cdot \frac{\mathrm{d} V_{\mathrm{s}}}{\mathrm{d} t}$, is attributed to three snow processes according to Eq. (1a-c).

$\rho_{\mathrm{s}} \cdot \frac{\mathrm{d} V_{\mathrm{s}}}{\mathrm{d} t}=\left\{\begin{array}{llll}P, & \text { for } T<T_{\mathrm{S}} & \text { Accumulation } & \text { (1a) } \\ P_{\mathrm{S}}-M & \text { for } T_{\mathrm{S}} \leq T \leq T_{\mathrm{R}} & \text { Combination } & \text { (1b) } \\ -\mathrm{DDF} \cdot\left(T-T_{\mathrm{m}}\right) & \text { for } T>T_{\mathrm{R}} & \text { Ablation, } & \text { (1c) }\end{array}\right.$

where $\rho_{\mathrm{S}}$ is the snow density, $P$ is daily precipitation, $P_{\mathrm{S}}$ is daily snowfall, $M$ is daily snowmelt depth, $T_{\mathrm{S}}$ is the temperature threshold below which all precipitation is in the form of snowfall, $T_{\mathrm{R}}$ is the temperature threshold above which all precipitation is liquid, and $T_{\mathrm{m}}$ is the temperature threshold controlling the occurrence of melt. $T_{\mathrm{m}}$ usually falls between $T_{\mathrm{S}}$ and $T_{\mathrm{R}}$. Rainfall and snowfall in the temperature window between $T_{\mathrm{S}}$ and $T_{\mathrm{R}}$ are simply estimated to be half of the total precipitation. The value of the three temperature thresholds are set as $T_{\mathrm{m}}=T_{\mathrm{S}}=0.0^{\circ} \mathrm{C}$ and $T_{\mathrm{R}}=2.5^{\circ} \mathrm{C}$ in this study following Parajka et al. (2007). The $V_{\mathrm{S}}$ time series are partitioned into three segments, i.e., accumulative segment, a combination segment and an ablative segment according to Eq. $(1 \mathrm{a}-\mathrm{c})$.

The snow density $\left(\rho_{\mathrm{s}}\right)$ is calculated from the days with accumulation based on the observed $V_{\mathrm{s}}$ and $P$ according to Eq. (1a). As the snow cover volume can still change after snowfall events due to gravity and condensation, snowfall events that produce a stable snow cover volume are selected for the estimation of snow density. Therefore, snowfall events in the accumulative segment that ended by at least 3 no-snowfall days, and where the relative difference of the $V_{\mathrm{s}}$ value between the last three no-snowfall days is lower than $10 \%$, are selected for the calculation of snow density. In these events, the cumulative snowfall $\left(\Delta P_{\mathrm{S}}\right)$ is the sum of the daily precipitation values, and the change of snow cover 
volume $\left(\Delta V_{\mathrm{s}}^{*}\right)$ is the difference of the $V_{\mathrm{s}}$ values between the last no-snowfall day and the first snowfall day. Snow density in each event is obtained as $\rho_{\mathrm{s}}=\Delta P_{\mathrm{s}} / \Delta V_{\mathrm{s}}^{*}$. This calculation is carried out for each subcatchment. A representative value of the density for each subcatchment is estimated to be the average of all event values, neglecting any changes of density during snow melt. While this is a simplification, it should be noted that the melt period is often interrupted by accumulation events, thus the differences between accumulation and ablation densities are not considered to be very large.

The snowmelt degree-day factor $\left(\mathrm{DDF}_{\mathrm{S}}\right)$ is calculated from days with ablation based on changes in the snow water equivalent and air temperatures according to Eq. (1c). The change of snow water equivalent between days is calculated as $\Delta V_{\mathrm{s}} \cdot \rho_{\mathrm{s}}$, where the density $\rho_{\mathrm{s}}$ estimated above is used. The degree-day temperature is calculated as the difference between the daily temperature $(T)$ and the threshold value $\left(T_{\mathrm{m}}\right)$. Daily $\mathrm{DDF}_{\mathrm{S}}$ value are then estimated as $\mathrm{DFF}_{\mathrm{S}}=\frac{\mathrm{d} V_{\mathrm{S}}}{\mathrm{d} t} \cdot \frac{\rho_{\mathrm{S}}}{T-T_{\mathrm{m}}}$. Again, a representative value of the degree-day factor for each subcatchment is estimated as the average of all event values. Both the estimations of snow density and $\mathrm{DDF}_{\mathrm{S}}$ are carried out in the two sub-periods (20012005 and 2006 to 2010) separately.

\subsection{Calibration of degree-day factor on runoff by a hydrologic model}

The runoff generation processes simulated by the THREW model includes subsurface baseflow, rainfall runoff, snowmelt and glacier melt. Rainfall runoff is simulated by a Xin'anjiang module, which adopts a water storage capacity curve to describe the non-uniform distribution of water storage capacity in a subcatchment (Zhao, 1992). The storage capacity curve is determined by two parameters (spatial averaged storage capacity $\mathrm{WM}$ and shape coefficient $B$ ). Rainfall runoff is generated on areas where the storage capacity is reached. The remainder of the rainfall infiltrates into the soil and becomes an additional contribution to subsurface baseflow which is calculated by two outflow coefficients (KKA and KKD). Snow and glacier melt are simulated by a degree-day model with different degree-day factors $\left(D_{D F}\right.$ and $D_{D D F}$, respectively). Precipitation in the snow covered areas is divided into rainfall and snowfall according to two threshold temperature values $\left(0\right.$ and $2.5^{\circ} \mathrm{C}$ are adopted in this study). Between the two thresholds, mixed snow and rain is assumed to occur. Snow water equivalent in each subcatchment is updated daily with snowfall and snowmelt, while the glacier area is assumed to be stable during the study period. The model parameters are grouped according to the runoff generation mechanisms, i.e., a subsurface baseflow group (KKA and KKD), a snowmelt group $\left(\mathrm{DDF}_{\mathrm{S}}\right)$, a glacier melt group $\left(\mathrm{DDF}_{\mathrm{G}}\right)$ and a group where rainfall directly becomes runoff (WM and $B$ ) (see He et al., 2014). Each parameter group is calibrated separately in a stepwise way by manual calibration. The stepwise calibration is similar to that proposed by $\mathrm{He}$ et al. (2014). In a first step, the hydrograph is partitioned according to three indices, $S_{i}, G_{i}, D_{i}$, which are defined as 0 or 1 (Eqs. 2-4) according to the water source for runoff generation on each day (subsurface baseflow, snowmelt, glacier melt and rainfall). Next, each parameter group is related to an individual hydrograph partition and calibrated on the corresponding partition separately.

$$
\begin{aligned}
S_{i} & =\left\{\begin{array}{l}
1, \text { if } \max _{j=1 \rightarrow 95}\left(T_{j}\right) \geq T_{\mathrm{m}} \\
0, \text { otherwise }
\end{array}\right. \text { Snowmelt, (2) } \\
G_{i} & =\left\{\begin{array}{l}
1, \text { if } \max _{j=1 \rightarrow n}\left(T_{j}^{\prime}\right) \geq T_{\mathrm{m}} \\
0, \text { otherwise }
\end{array}\right. \text { Glacier melt, (3) } \\
D_{i} & =\left\{\begin{array}{l}
1, \text { if } \max _{j=1 \rightarrow 95}\left(T_{j}\right) \geq T_{\mathrm{S}} \wedge \sum_{j=1 \rightarrow 95} P_{j} \geq 0 \\
0, \text { otherwise }
\end{array} \quad\right. \text { Rainfall runoff, }
\end{aligned}
$$

where, $i$ is the day index, $S_{i}, G_{i}$ and $D_{i}$ are the indices indicating the occurrence of snowmelt, glacier melt and rainfall runoff, respectively. Values equal to 1 indicate that snowmelt, glacier melt and rainfall runoff, respectively, can be a water source for runoff generation on that day. Values equal to 0 indicate that this is not the case. $T_{j}$ is the daily temperature in the subcatchment $j, T_{j}^{\prime}$ is the daily temperature in the glacier covered subcatchment $j, n$ is the number of subcatchment that are covered with glacier, and $P_{j}$ is the daily precipitation in subcatchment $j$. Based on the daily values of the three indices, the daily hydrograph is segmented into four partitions in Eq. (5):

$$
Q= \begin{cases}Q_{\mathrm{SB}}, & \text { for } S_{i}+G_{i}+D_{i}=0 \\ Q_{\mathrm{SB}}+Q_{\mathrm{SM}}, & \text { for } S_{i}-G_{i}-D_{i}=1 \\ Q_{\mathrm{SB}}+Q_{\mathrm{SM}}+Q_{\mathrm{GM}}, & \text { for } G_{i}-D_{i}=1 \\ Q_{\mathrm{SB}}+Q_{\mathrm{SM}}+Q_{\mathrm{GM}}+Q_{\mathrm{R}}, & \text { for } D_{i}=1\end{cases}
$$

where, $Q_{\mathrm{SB}}$ stands for the subsurface baseflow. It dominates the basin hydrograph when both melt water and rainfall runoff do not occur $\left(S_{i}+G_{i}+D_{i}=0\right)$. $Q_{\mathrm{SM}}$ represents snowmelt, $Q_{\mathrm{GM}}$ represents glacier melt water and $Q_{\mathrm{R}}$ represents the direct rainfall runoff. The partition is based on the assumption that the convergence time of drainage in the basin is no longer than 1 day.

The parameter groups are calibrated on different partitions in a stepwise way: The parameter group controlling subsurface baseflow is first calibrated on the $Q_{\mathrm{SB}}$ partition. Then, the degree-day factors for snowmelt and glacier melt are calibrated on the $Q_{\mathrm{SB}}+Q_{\mathrm{SM}}$ and $Q_{\mathrm{SB}}+Q_{\mathrm{SM}}+Q_{\mathrm{GM}}$ partitions separately. Parameters for rainfall runoff are calibrated on the $Q_{\mathrm{SB}}+Q_{\mathrm{SM}}+Q_{\mathrm{GM}}+Q_{\mathrm{R}}$ partition in a last step. We use $\operatorname{logRMSE}$ as the goodness of fit measure for the calibration of subsurface baseflow and RMSE for the calibration of degree-day factors and rainfall runoff parameters. Finally, we combine the simulations of each partition to obtain 
the entire daily simulation of basin discharge and evaluating it using Nash-Sutcliffe efficiency (NSE), logarithmic NashSutcliffe efficiency (losNSE), volumetric deviation (VE) and combined measure (ME) (Eqs. 6-9).

$\mathrm{NSE}=1-\frac{\sum_{i=1}^{n}\left(Q_{\mathrm{obs}}(i)-Q_{\mathrm{sim}}(i)\right)^{2}}{\sum_{i=1}^{n}\left(Q_{\mathrm{obs}}(i)-\bar{Q}_{\mathrm{obs}}(i)\right)^{2}}$

$\operatorname{logNSE}=1-\frac{\sum_{i=1}^{n}\left(\log Q_{\mathrm{obs}}(i)-\log Q_{\mathrm{sim}}(i)\right)^{2}}{\sum_{i=1}^{n}\left(\log Q_{\mathrm{obs}}(i)-\log \bar{Q}_{\mathrm{obs}}(i)\right)^{2}}$

$\mathrm{VE}=1-\frac{\sum_{i=1}^{n}\left|Q_{\mathrm{obs}}(i)-Q_{\operatorname{sim}}(i)\right|}{\sum_{i=1}^{n} Q_{\mathrm{obs}}(i)}$

$\mathrm{ME}=\mathrm{NSE}+\log \mathrm{NSE}+\mathrm{VE}$

$\mathrm{RMSE}=\sqrt{\frac{1}{n} \sum_{i=1}^{n}\left(Q_{\mathrm{obs}}(i)-Q_{\mathrm{sim}}(i)\right)^{2}}$

\subsection{Evaluation of estimated $\mathrm{DDF}_{\mathrm{S}}$ from snow data}

The estimated values of $\mathrm{DDF}_{\mathrm{S}}$ are evaluated in the study period by applying their value in the THREW hydrological model and comparing the new simulations of runoff and snow cover patterns with those obtained by $\mathrm{DDF}_{\mathrm{S}}$ calibrated on runoff. The evaluation is carried out in three basins with different catchment area, elevation and glacier melt contributions to the total runoff. The ME values of daily discharge simulation and RMSE values of the simulation of the snowmelt dominated hydrograph partition $\left(Q_{\mathrm{SB}}+Q_{\mathrm{SM}}\right)$ in the three basins are used to evaluate the performance of the runoff simulation. The fit between simulated and observed SCA series and spatial snow cover patterns by MODIS is used to assess the simulations of snow cover.

\section{Data}

\subsection{Study area}

The methodology is evaluated in the Lienz catchment which is located in East Tyrol, Austria, and covers an area of $1198 \mathrm{~km}^{2}$. Its elevations range from 670 to $3775 \mathrm{ma}$ a.s.1., and approximately $7 \%$ of the region is covered by glacier (Fig. 1). Its annual mean temperature is approximately $1.7^{\circ} \mathrm{C}$, and annual mean precipitation is about $1164 \mathrm{~mm}$. Snowmelt water is an important water source for local runoff generation, especially in the spring season when approximately $70 \%$ of the basin is covered by snow (Blöschl et al., 1990). The topographic feature of the basin is depicted by a $25 \mathrm{~m}$ resolution digital elevation model, which is used to

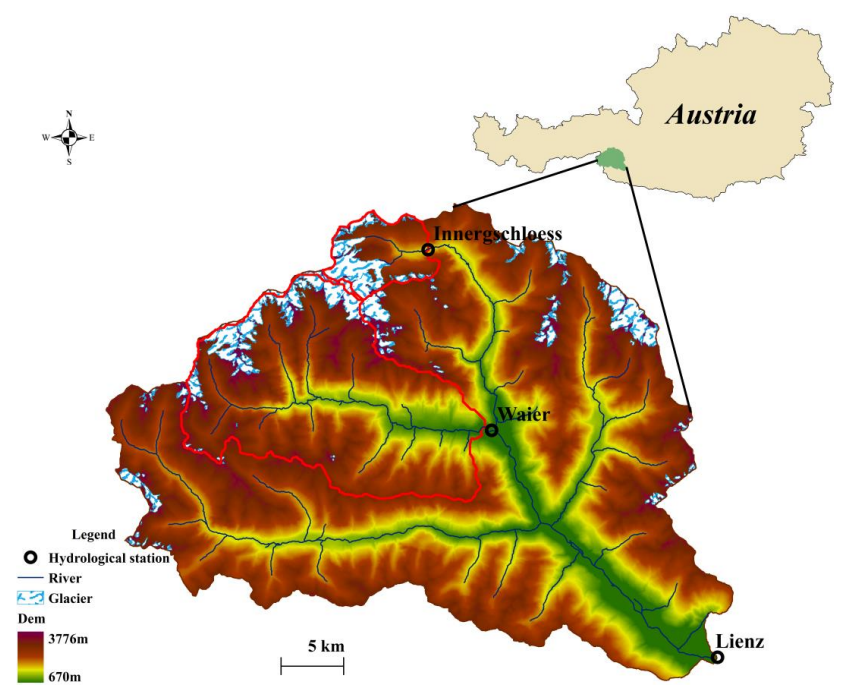

Figure 1. Location of the study area in Austria. Three catchments are analyzed, Lienz, Waier, and Innergschloess, with areas of 1190, 285 , and $39 \mathrm{~km}^{2}$, respectively. The glacier coverage in the three basins is approximately 7,13 , and $29 \%$.

divide the study basins into subcatchment units. The three basins (Lienz, Waier and Innergschloess, see Fig. 1) in the study area are further divided into 95 subcatchments, 29 subcatchments and 9 subcatchments respectively for the hydrological modeling. The runoff concentration time can be considered as approximately 1 day in this catchment (Blöschl et al., 1990).

\subsection{Snow data}

The MODIS snow covered area (SCA) data used in this study is the daily product, i.e., MOD10A1 and MYD10A1 (V005) (Hall et al., 2006a, b). It has been downloaded from the website of the National Snow and Ice Data Center (NSIDC, www.nsidc.org). The used data set has a spatial resolution of $500 \mathrm{~m}$ and consists of daily snow cover maps from 1 January 2001 to 31 December 2010. The original Terra and Aqua products were merged in space and time to reduce cloud coverage by Parajka and Blöschl (2008b). Only the MODIS SCA data for those days when the cloud coverage of the basin was less than $50 \%$ after the merging procedure are used. To obtain a continuous time series of SCA, we implemented a linear interpolation between two valid SCA values.

Snow depth data observed at 1091 stations in Austria (seven stations in the study area) are spatially interpolated by external drift kriging based on elevation. The resulting data product has a spatial resolution of $1 \mathrm{~km}$. Snow depth in each subcatchment is the average value of all the $1 \times 1 \mathrm{~km}$ pixels inside. 

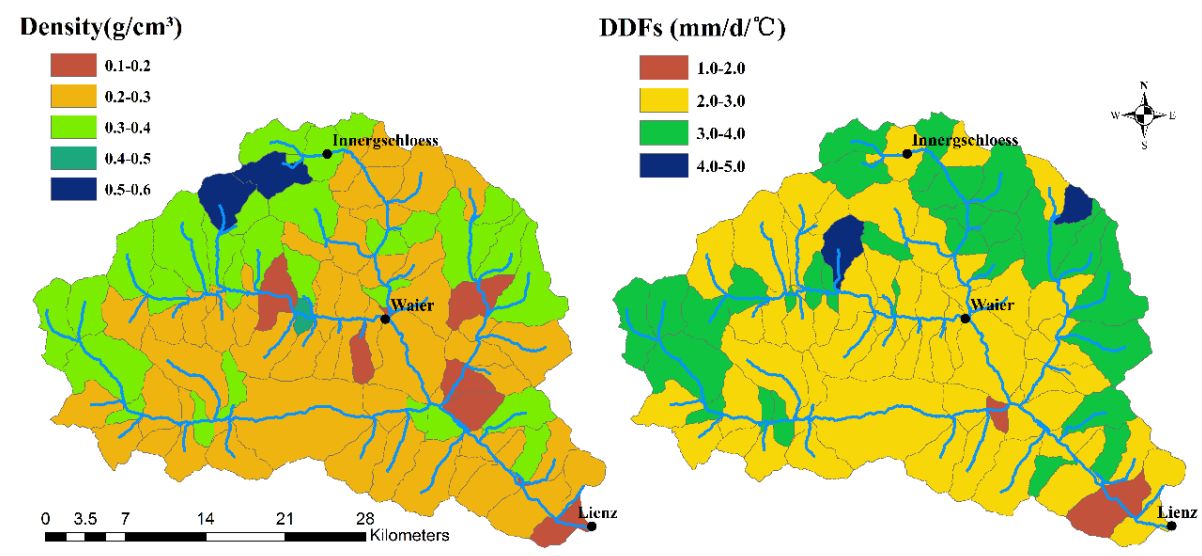

Figure 2. Spatial distribution of the snow density and the snowmelt degree-day factor $\left(\mathrm{DDF}_{\mathrm{S}}\right)$ estimated by the proposed method in the Lienz basin. Black dots indicate the stream gauges.

\subsection{Hydrologic model inputs}

The daily precipitation data are spatially interpolated by external drift kriging from 1091 stations in Austria (seven stations in the study area). The temperature data are interpolated by the least-squares trend prediction method from 221 stations in Austria (six stations in the study area). Both methods using elevation as an auxiliary variable (see Parajka et al., 2005). Daily streamflow data from three hydrological stations are used, Lienz, Waier and Innergschloess, which drain areas of 1198, 285 and $39 \mathrm{~km}^{2}$, respectively (see Fig. 1). The data sets used in this study consist of two sub-periods, the first is a calibration period from 1 January 2001 to 31 December 2005 and the second is a validation period from 1 January 2006 to 31 December 2010.

\section{Results}

\subsection{Snow density and $D_{D F}$}

Based on Eq. (1a, c), we obtained the snow densities and snowmelt degree-day factors $\left(\mathrm{DDF}_{\mathrm{S}}\right)$ for each subcatchment in the Lienz basin. For example, Figs. 2 and 3 show the spatial distribution of the snow density and $\mathrm{DDF}_{\mathrm{S}}$ estimated in the calibration period. Figure 2 indicates that subcatchments in upstream have higher snow density and $\mathrm{DDF}_{\mathrm{S}}$ values than that in downstream. Figure 3 represents the relationships between snow density and elevation, and $\mathrm{DDF}_{\mathrm{S}}$ and elevation. Leaf area index (LAI) data from MODIS land cover products are used to describe the vegetation coverage in each subcatchment in Fig. 3. Each dot stands for a subcatchment, and its size reflects the annual mean LAI over the study period of the corresponding subcatchment. The estimated values of snow density range from approximately 0.1 to $0.6 \mathrm{~g} \mathrm{~cm}^{-3}$ with a mean value of $0.3 \mathrm{~g} \mathrm{~cm}^{-3}$. The estimated values of $\mathrm{DDF}_{\mathrm{S}}$ range from about 1.6 to $4.5 \mathrm{~mm} \mathrm{day}^{-1}{ }^{\circ} \mathrm{C}^{-1}$ with an average of $2.7 \mathrm{~mm} \mathrm{day}^{-1}{ }^{\circ} \mathrm{C}^{-1}$.
$\mathrm{DDF}_{\mathrm{S}}$ values in the medium sized Waier basin mainly fall into a range of $2.0-3.0 \mathrm{~mm}_{\text {day }}{ }^{-1}{ }^{\circ} \mathrm{C}^{-1}$, while in the smallest basin, the Innergschloess, they fall into a range of 2.0$4.0 \mathrm{~mm}$ day $^{-1}{ }^{\circ} \mathrm{C}^{-1}$ (see Fig. 2). Generally, both the snow density and $\mathrm{DDF}_{\mathrm{S}}$ values increase with increasing elevation (see Fig. 3), as would be expected. The value of snow density can be affected by the duration of the snow cover. In high elevation subcatchments, temperatures tend to be lower which leads to more snowfall and more opportunity for compaction and settling which, in turn, tends to result in higher snow densities (Rango and Martinec, 1995). The spatial pattern of $\mathrm{DDF}_{S}$ can be attributed to the interaction of climate and basin topography as well as vegetation: At higher elevations, soils tend to be thin and air temperatures tend to be low, which are unfavorable conditions for the growth of vegetation. Therefore, the share of latent heat of transpiration in the energy balance is lower. Lower temperatures at higher elevation also reduce the share of sensible heat (Musselman et al., 2012). Coupling with a stronger solar radiation due to lower cloudiness, stronger snowmelt is produced at higher elevations relative to the difference between daily temperature $(T)$ and the threshold value $\left(T_{\mathrm{m}}\right)$. Higher elevations are also associated with steep terrain which reinforces the melt rate by increasing the solar incident angle on the south facing slopes (Blöschl et al., 1991a, b; Blöschl and Kirnbauer, 1992). At lower elevations, climate conditions are favorable for the growth of vegetation, which produce a higher share of latent heat by transpiration and restrain the snowmelt. On the other hand, higher vegetation canopies may contribute to higher soil water contents which may increase the albedo of the land surface and may reduce the energy available for snowmelt (Kuusisto, 1980). The moist soil can also enhance the temperature gradient and create sharp gradients in sensible heat fluxes (Entekhabi et al., 1996) and allow fast redistribution of soil moisture at small scales (Western et al., 1998). Changes of the heat conditions in the near surface atmosphere in turn may change the soil moisture state and may 

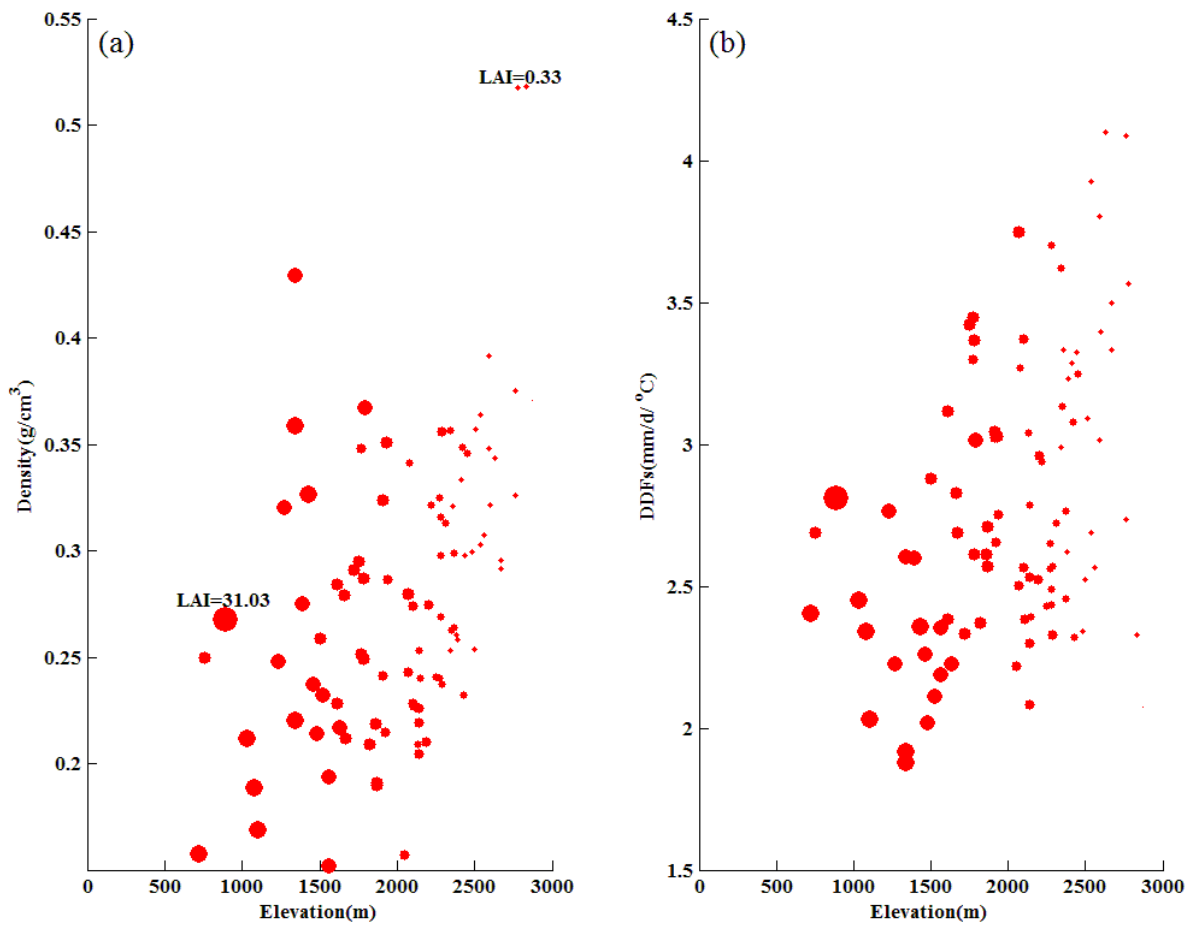

Figure 3. Snow density and snowmelt degree-day factor $\left(D_{D} F_{S}\right)$ estimated by the proposed method plotted against elevation in the Lienz basin. Each dot represents a subcatchment in the basin. The size of dots increases with increasing of mean leaf area index (LAI) over the study period (2001-2010) which is derived from MODIS. LAI values in the basin range between 0.33 and 31.03.

promote vegetation growth. The spatial variability of snow density and $\mathrm{DDF}_{\mathrm{S}}$ is likely the combined result of a number of factors, including slope aspect, wind speed and shading, in addition to elevation and vegetation.

\subsection{Transferability in time of the estimated $\mathrm{DDF}_{S}$}

The data set used in this study has been divided into two subperiods: calibration period from 1 January 2001 to 31 December 2005 and validation period from 1 January 2006 to 31 December 2010. The average annual precipitation is 1126 $\mathrm{mm}$ in the calibration period, and $1238 \mathrm{~mm}$ in the validation period. The mean daily temperature is $2.28^{\circ} \mathrm{C}$ in the calibration period, and $2.59^{\circ} \mathrm{C}$ in the validation period. Mean daily snow coverage from MODIS is approximately $10 \%$ in the calibration period, and about $12 \%$ in the validation period. Although the difference of the climate and snow cover conditions in the two periods is small, it can still play a role in the snowmelt processes. Therefore, we re-estimated the value of snow density and $\mathrm{DDF}_{\mathrm{S}}$ using the climate data and MODIS snow data in the validation period and compared the new estimated $\mathrm{DDF}_{\mathrm{S}}$ set with that estimated using data in the calibration period in Fig. 4. The comparison shows that the two estimated sets of $\mathrm{DDF}_{\mathrm{S}}$ and snow density (SD) are slight different due to the different climate and snow cover conditions in the two sub-periods. However, the correlation coefficients between the two estimated $\mathrm{DDF}_{\mathrm{S}}$ sets and that between the two SD sets are both high, i.e., 0.802 for the $\mathrm{DDF}_{\mathrm{S}}$ and 0.720 for the SD (see Fig. 4), which indicates that both the two estimated $\mathrm{DDF}_{\mathrm{S}}$ sets and two SD sets are consistent in the two sub-periods. There is no significant systematic bias for the estimated $\mathrm{DDF}_{\mathrm{S}}$ and $\mathrm{SD}$. This suggests the transferability in time of the estimated $\mathrm{DDF}_{\mathrm{S}}$ in the whole study period. To further test its transferability in time, we applied $\mathrm{DDF}_{\mathrm{S}}$ values estimated in one period for the simulation of basin discharge and snow cover in the other period. For example, in the following Sect. 4.4, we used the DDFS set estimated by snow data in the calibration period (2001 to 2005 ) for the model simulation in the validation period (2006 to 2010).

\subsection{Stepwise calibration}

Model parameters in the three basins are calibrated on the corresponding hydrograph partitions separately (see He et al., 2014). After the calibration, we combined the simulations of the four partitions and obtained the entire simulation of daily discharge. As an example, the simulation in each step in the largest basin, the Lienz basin, is shown in Fig. 5, using the calibrated degree-day factors for snowmelt and glacier melt as $2.6 \mathrm{~mm}$ day $^{-1}{ }^{\circ} \mathrm{C}^{-1}$ and $3.5 \mathrm{~mm}$ day $^{-1}{ }^{\circ} \mathrm{C}^{-1}$, respectively, as shown in Table 1. The logRMSE and RMSE values in Fig. 5 suggest that the simulations of each hydrograph partition are very reasonable. The calibrated parameter set was 

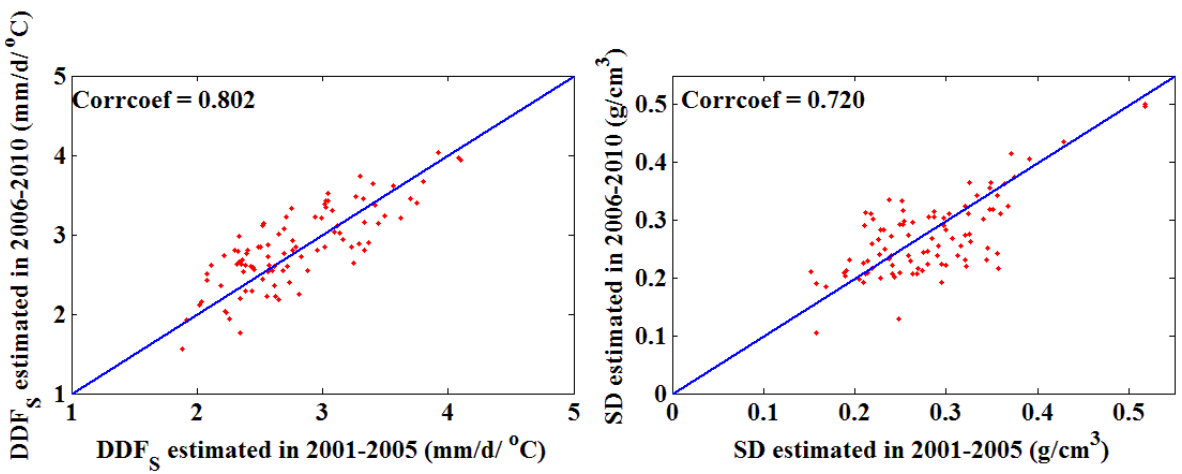

Figure 4. Comparison of the estimated degree-day factor for snowmelt $\left(\mathrm{DDF}_{\mathrm{S}}\right)$ and snow density $(\mathrm{SD})$ in two sub-periods. "Corrcoef" is the value of correlation coefficient between two estimated sets.
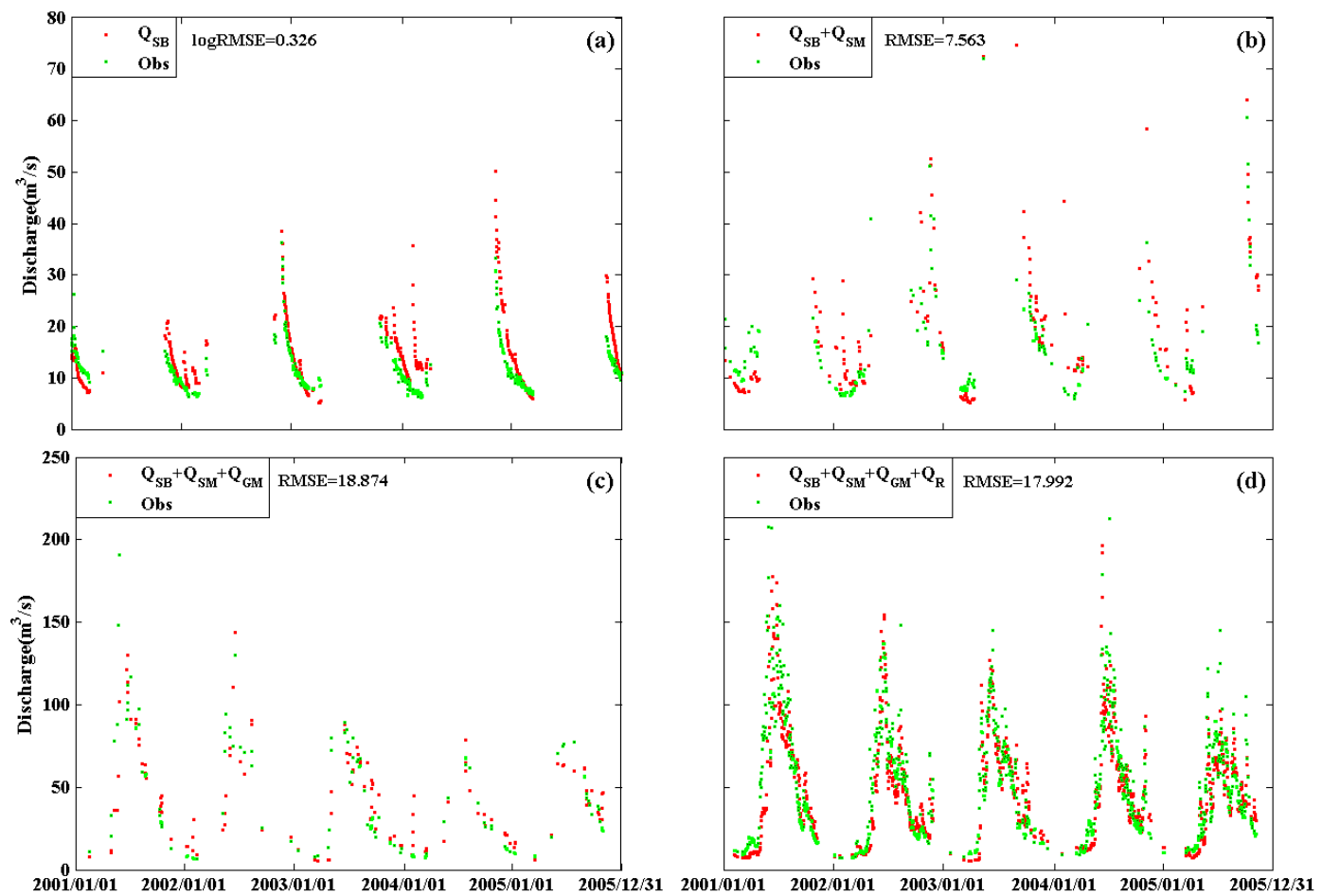

Figure 5. Stepwise calibration results for the Lienz basin in the calibration period. (a) is the first calibration step in which the parameters controlling groundwater baseflow are calibrated, (b) to (d) are the subsequent three steps of calibrating melt factors and rainfall runoff parameters. $Q_{\mathrm{SB}}, Q_{\mathrm{SM}}, Q_{\mathrm{GM}}$ and $Q_{\mathrm{R}}$ are the simulated discharges that are generated by baseflow, snowmelt, glacier melt and rainfall, respectively.

also tested for the validation period (2006-2010), as shown in Fig. 6. Again, the performance is very reasonable as indicated by NSE and logNSE. For example, in the Lienz basin NSE values are 0.817 and 0.833 in the calibration and validation periods, respectively, indicating the suitability of the calibrated parameter set. The simulation performances for the two sub-basins (Waier and Innergschloess) are also shown in Table 1.

The calibrated $\mathrm{DDF}_{\mathrm{S}}$ and $\mathrm{DDF}_{\mathrm{G}}$ are slight different in the three basins. $\mathrm{DDF}_{\mathrm{S}}$ ranges from 1.0 to $2.6 \mathrm{~mm} \mathrm{day}^{-1}{ }^{\circ} \mathrm{C}^{-1}$, and $\mathrm{DDF}_{\mathrm{G}}$ ranges from 3.5 to $6.0 \mathrm{~mm}$ day $^{-1}{ }^{\circ} \mathrm{C}^{-1}$. The calibrated $\mathrm{DDF}_{\mathrm{S}}$ in the Lienz and Waier basins are similar to those estimated from MODIS and snow depth data in Sect. 4.1 , while the calibrated value, $1.0 \mathrm{~mm} \mathrm{day}^{-1}{ }^{\circ} \mathrm{C}^{-1}$, in the Innergschloess basin is clearly different from the estimated values that range from 2.0 to $4.0 \mathrm{~mm}$ ayy $^{-1}{ }^{\circ} \mathrm{C}^{-1}$. Given the role of radiation in this high elevation basin, the value of $1.0 \mathrm{~mm}$ day ${ }^{-1}{ }^{\circ} \mathrm{C}^{-1}$ seems far too low, and the snowdata-based estimate is much more reasonable. 
Table 1. Performance of discharge simulations in three basins. $\mathrm{DDF}_{\mathrm{S}}$ is the snowmelt degree-day factor and $\mathrm{DDF}_{\mathrm{G}}$ is the glacier melt

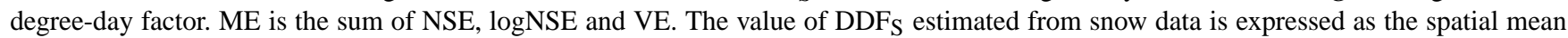

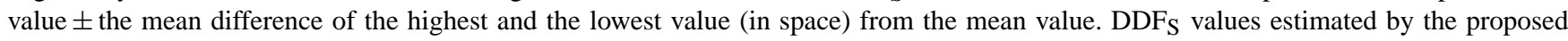
method are shown in bold.

\begin{tabular}{|c|c|c|c|c|c|c|c|}
\hline & & \multicolumn{2}{|c|}{ Lienz } & \multicolumn{2}{|c|}{ Waier } & \multicolumn{2}{|c|}{ Innergschloess } \\
\hline & & $\begin{array}{l}\text { Calibration } \\
\text { period }\end{array}$ & $\begin{array}{l}\text { Validation } \\
\text { period }\end{array}$ & $\begin{array}{l}\text { Calibration } \\
\text { period }\end{array}$ & $\begin{array}{l}\text { Validation } \\
\text { period }\end{array}$ & $\begin{array}{l}\text { Calibration } \\
\text { period }\end{array}$ & $\begin{array}{l}\text { Validation } \\
\text { period }\end{array}$ \\
\hline \multirow{6}{*}{$\begin{array}{l}\mathrm{DDF}_{\mathrm{S}} \\
\text { calibrated on } \\
\text { runoff }\end{array}$} & $\mathrm{DDF}_{\mathrm{S}}\left(\mathrm{mm} \mathrm{day}^{-1}{ }^{\circ} \mathrm{C}^{-1}\right)$ & 2.6 & 2.6 & 2.6 & 2.6 & 1.0 & 1.0 \\
\hline & $\mathrm{DDF}_{\mathrm{G}}\left(\mathrm{mm} \mathrm{day}^{-1}{ }^{\circ} \mathrm{C}^{-1}\right)$ & 3.5 & 3.5 & 4.2 & 4.2 & 6.0 & 6.0 \\
\hline & NSE & 0.817 & 0.833 & 0.832 & 0.863 & 0.804 & 0.726 \\
\hline & $\operatorname{logNSE}$ & 0.851 & 0.873 & 0.849 & 0.871 & 0.825 & 0.871 \\
\hline & $\mathrm{VE}$ & 0.762 & 0.758 & 0.739 & 0.770 & 0.654 & 0.585 \\
\hline & ME & 2.430 & 2.464 & 2.420 & 2.504 & 2.283 & 2.182 \\
\hline \multirow{6}{*}{$\begin{array}{l}\mathrm{DDF}_{\mathrm{S}} \\
\text { estimated from } \\
\text { snow data }\end{array}$} & $\mathrm{DDF}_{\mathrm{S}}\left(\mathrm{mm}\right.$ day $\left.^{-1}{ }^{\circ} \mathrm{C}^{-1}\right)$ & $2.7 \pm 1.1$ & $2.7 \pm 1.1$ & $2.6 \pm 0.9$ & $2.6 \pm 0.9$ & $3.2 \pm 0.3$ & $3.2 \pm 0.3$ \\
\hline & $\mathrm{DDF}_{\mathrm{G}}\left(\mathrm{mm} \mathrm{day}^{-1}{ }^{\circ} \mathrm{C}^{-1}\right)$ & 3.5 & 3.5 & 4.2 & 4.2 & 6.0 & 6.0 \\
\hline & NSE & 0.810 & 0.826 & 0.835 & 0.845 & 0.801 & 0.768 \\
\hline & $\operatorname{logNSE}$ & 0.845 & 0.867 & 0.845 & 0.869 & 0.826 & 0.885 \\
\hline & $\mathrm{VE}$ & 0.751 & 0.746 & 0.740 & 0.760 & 0.648 & 0.628 \\
\hline & $\mathrm{ME}$ & 2.406 & 2.439 & 2.420 & 2.474 & 2.275 & 2.281 \\
\hline
\end{tabular}

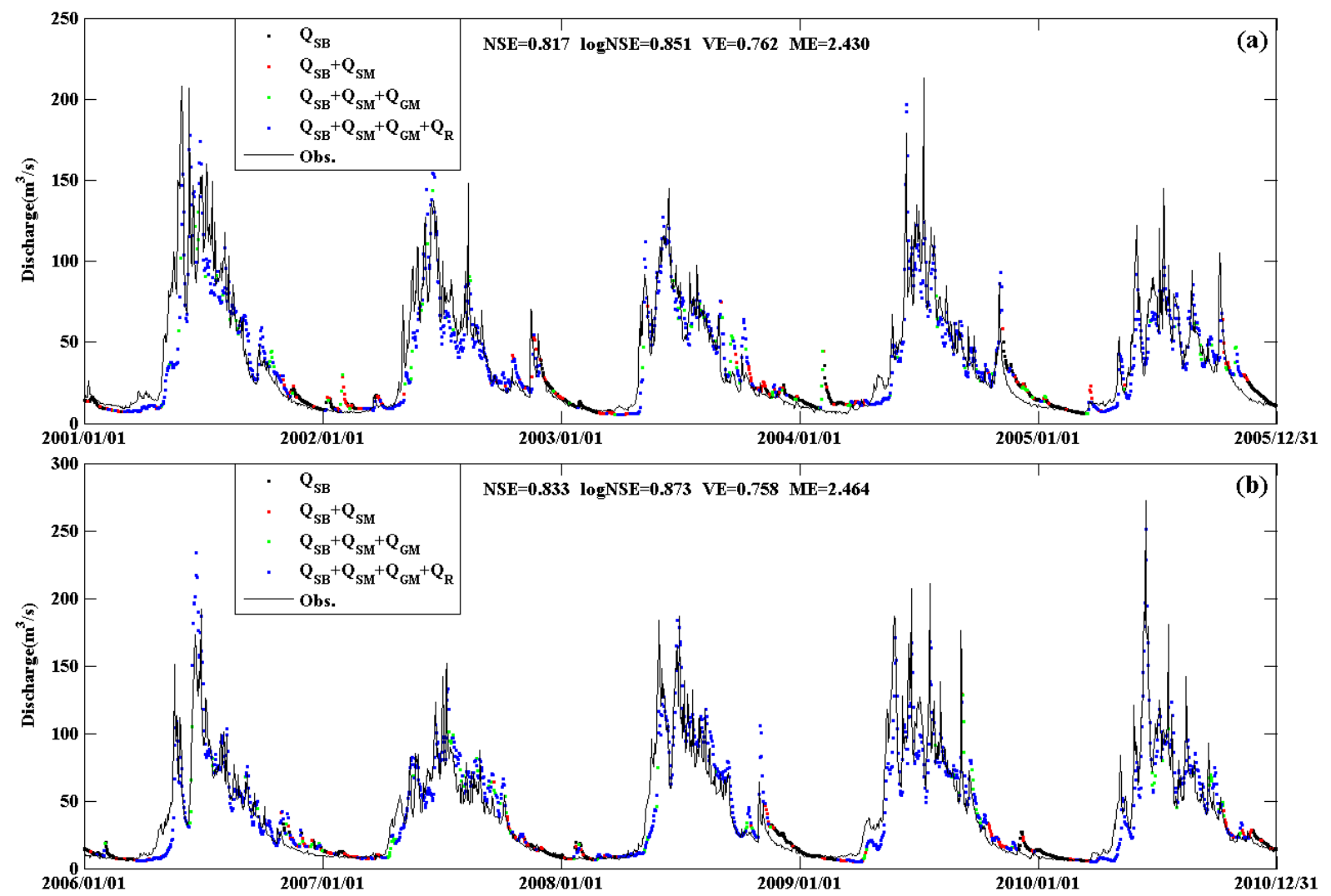

Figure 6. Simulation of daily discharge in the Lienz basin using the snowmelt degree-day factor calibrated on runoff. (a) is for the calibration period and (b) is for the validation period. The entire daily simulated discharge hydrograph has been combined from the simulations of different runoff segments. $Q_{\mathrm{SB}}$ stands for the simulated runoff generated by groundwater baseflow, $Q_{\mathrm{SM}}$ and $Q_{\mathrm{GM}}$ indicate simulated runoff generated by snow and glacier melt, and $Q_{\mathrm{R}}$ is the simulated runoff generated by rainfall directly. Performance measures of the simulations are shown at the top of each panel. 


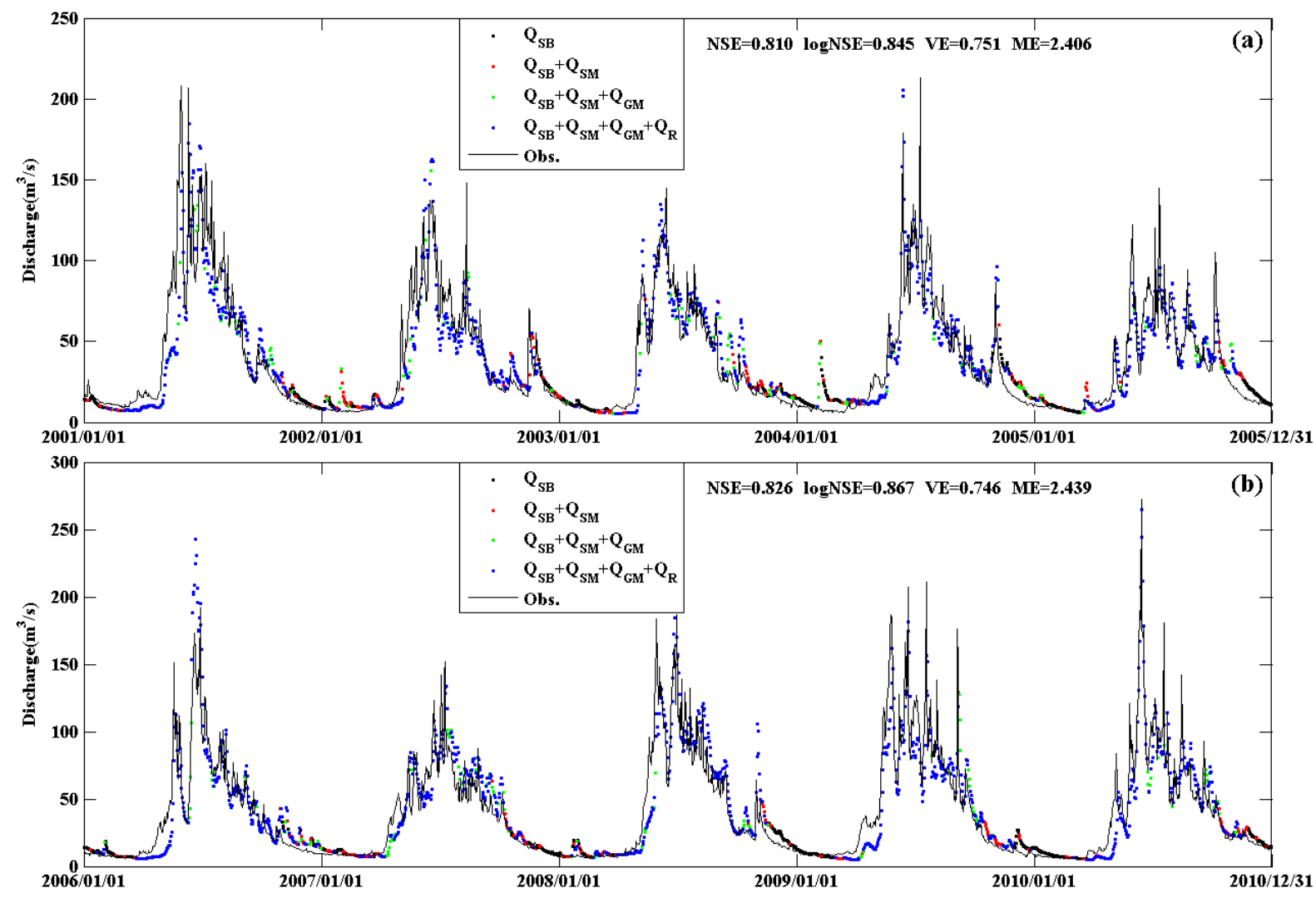

Figure 7. Same as Fig. 6 but using snowmelt degree-day factors estimated from snow data.

The runoff simulations in the medium basin (Waier) are the best with an NSE value of 0.832 in the calibration period and 0.863 in the validation period. Runoff simulations in the smallest basin (Innergschloess) exhibit a slightly lower performance with an NSE value of 0.726 in the validation period. This may be partly due to the remarkably low value of the calibrated $\mathrm{DDF}_{\mathrm{S}}$, i.e., $1.0 \mathrm{~mm}$ day ${ }^{-1}{ }^{\circ} \mathrm{C}^{-1}$. The calibration of $\mathrm{DDF}_{\mathrm{S}}$ relies heavily on the observed hydrographs, which may introduce uncertainties in the $\mathrm{DDF}_{\mathrm{S}}$ estimates in some cases.

\subsection{Evaluation of estimated $\mathrm{DDF}_{\mathrm{S}}$}

To evaluate the estimated $\mathrm{DDF}_{\mathrm{S}}$, we replaced the calibrated $\mathrm{DDF}_{\mathrm{S}}$ in the model with the ones estimated from snow data, and re-ran the hydrological simulation. The other model parameters remained the same as those calibrated in Sect. 4.3. The new simulation results in the three basins are summarized in Table 1 . The simulations using the spatially variable $\mathrm{DDF}_{\mathrm{S}}$ estimated from snow data tend to perform better than those using the calibrated, spatially uniform $\mathrm{DDF}_{\mathrm{S}}$. In the Lienz and Waier basins, the new simulations are similar to those shown in Sect. 4.3, as demonstrated by the ME values in Table 1. For example, Fig. 7 presents the new simulation for the Lienz basin with an NSE value of 0.810 in the calibration period and 0.826 in the validation period. Both are very similar to the NSE values shown in Fig. 6 . The mean value of the estimated $\mathrm{DDF}_{\mathrm{S}}$ in these two basins are 2.7 and $2.6 \mathrm{~mm}$ day ${ }^{-1}{ }^{\circ} \mathrm{C}^{-1}$, respectively, both are similar to the calibrated value of $2.6 \mathrm{~mm} \mathrm{day}^{-1}{ }^{\circ} \mathrm{C}^{-1}$. It is worth noting that the new simulation in the smallest Innergschloess basin is significantly better, especially in the validation period, considering the ME values in Table 1. The mean value of the estimated $\mathrm{DDF}_{\mathrm{S}}$ in this basin is $3.2 \mathrm{~mm}$ day ${ }^{-1}{ }^{\circ} \mathrm{C}^{-1}$ which is clearly different from the calibrated value. This suggests that the calibrated $\mathrm{DDF}_{\mathrm{S}}$ value of $1.0 \mathrm{~mm} \mathrm{day}^{-1}{ }^{\circ} \mathrm{C}^{-1}$ in this small, high elevation basin may not be accurate.

As the $D_{D F}$ value has the most sensitive effect on the snowmelt dominated hydrograph partition $\left(Q_{\mathrm{SB}}+Q_{\mathrm{SM}}\right)$, we focus on the simulation of this partition by the two DDFS sets in Fig. 8. The simulation performance is evaluated using RMSE. The first two rows in Fig. 8 show the simulations using calibrated (Fig. 8a-c) and estimated (Fig. 8d-f) DDF in the calibration period, and the last two rows present the simulations in the validation period (Fig. $8 \mathrm{~g}-\mathrm{i}$ is for $\mathrm{DDF}_{\mathrm{S}}$ calibrated on runoff and Fig. $8 \mathrm{j}-1$ is for $\mathrm{DDF}_{\mathrm{S}}$ estimated from snow data). The differences of the RMSE values obtained by the two $\mathrm{DDF}_{\mathrm{S}}$ sets in the Lienz basin (first column) range from 0.132 to $0.347 \mathrm{~m}^{3} \mathrm{~s}^{-1}$. Considering the relatively higher levels of the discharge, the two simulations can still 

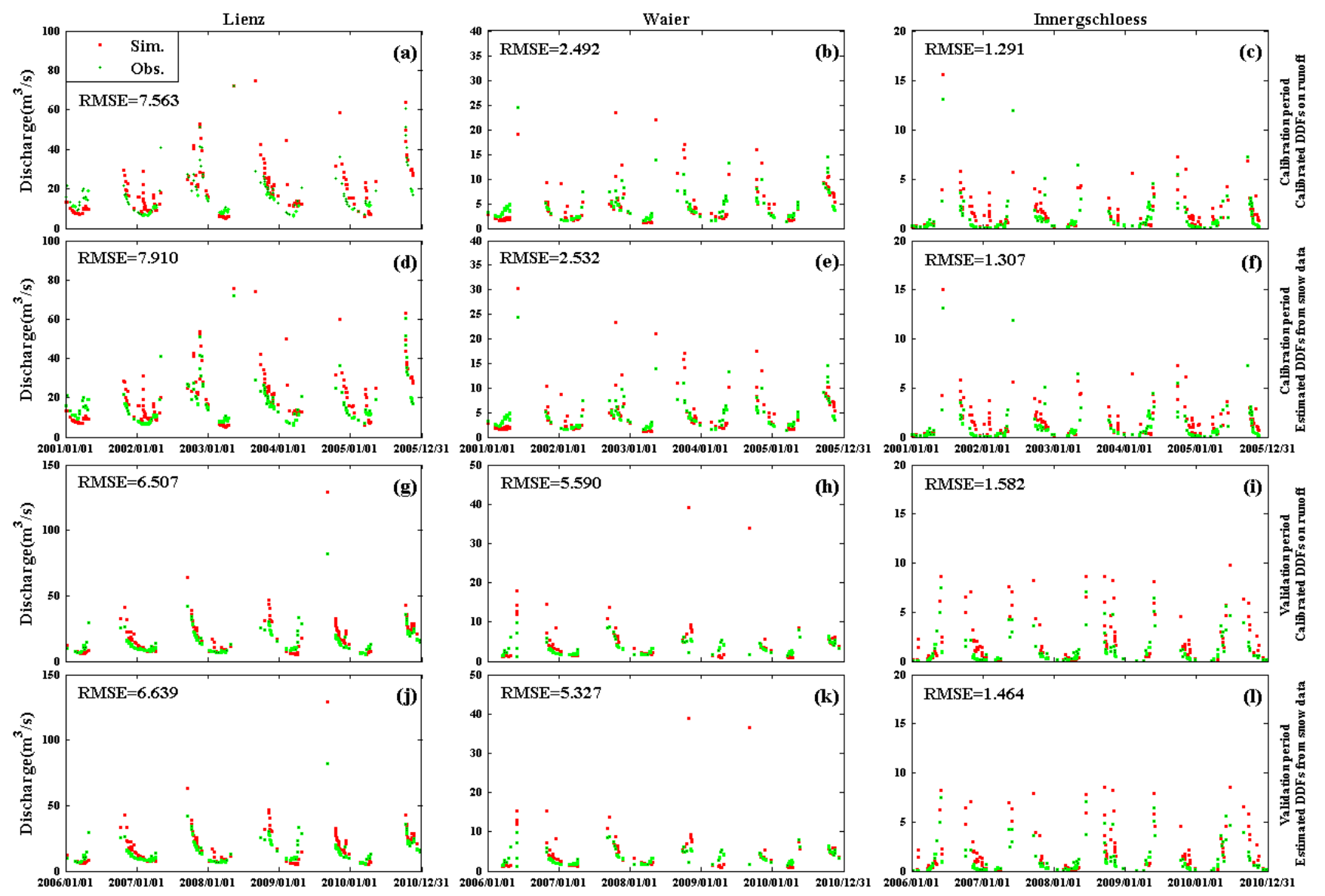

Figure 8. Simulations of discharge segments generated by groundwater baseflow $\left(Q_{\mathrm{SB}}\right)$ and snowmelt $\left(Q_{\mathrm{SM}}\right)$ in the three basins. (a)-(c) are simulations for the calibration period using $\mathrm{DDF}_{\mathrm{S}}$ calibrated on runoff, (d)-(f) are simulation for the calibration period using DDF estimated from snow data, (g)-(i) are simulations for the validation period using DDFS calibrated on runoff, (j)-(l) are simulations for the validation period using $\mathrm{DDF}_{\mathrm{S}}$ estimated from snow data. The discharge simulations are evaluated using the RMSE $\left(\mathrm{m}^{3} \mathrm{~s}^{-1}\right)$.

be regarded as very close. As to the Waier basin (second column), the RMSE value obtained by the estimated $\mathrm{DDF}_{\mathrm{S}}$ in the calibration period is slightly higher $\left(0.04 \mathrm{~m}^{3} \mathrm{~s}^{-1}\right.$ higher $)$ but much lower $\left(0.263 \mathrm{~m}^{3} \mathrm{~s}^{-1}\right.$ lower $)$ in the validation period. In Innergschloess basin (third column), the RMSE values in the calibration period are as close as a slight difference of $0.016 \mathrm{~m}^{3} \mathrm{~s}^{-1}$, while in the validation period the RMSE value obtained by the estimated $\mathrm{DDF}_{\mathrm{S}}$ is $0.118 \mathrm{~m}^{3} \mathrm{~s}^{-1}$ lower than that obtained by the calibrated $D_{D F}$. Comparisons of the simulations of the $Q_{\mathrm{SB}}+Q_{\mathrm{SM}}$ hydrograph partition show a similar performance in the calibration period but a better performance of estimated $\mathrm{DDF}_{\mathrm{S}}$ in the validation period. Overall, the comparisons for the three basins shown in Table 1 and Fig. 8 suggest that the DDF values estimated from snow data by the new method tend to produce a somewhat better runoff simulation performance.

We also assess the suitability of the estimated $\mathrm{DDF}_{\mathrm{S}}$ values by examining the snow cover simulations in the study basins. The match between simulated snow cover and observed snow cover from MODIS is illustrated in Figs. 9 to 12. The THREW model simulates snow water equivalent (SWE) in each subcatchment. To obtain the snow covered area (SCA) in the basin, we define a threshold value for the simulated SWE $\left(\mathrm{SWE}_{\mathrm{T}}\right)$, above which the sub unit of the basin (i.e., subcatchment) is considered to be fully covered by snow, and below it the subcatchment is considered snow free. Subsequently, we obtain the simulated time series of SCA of the study basin. For example, Fig. 9 shows the comparison of simulated SCA using $\mathrm{DDF}_{\mathrm{S}}$ calibrated on runoff and $\mathrm{DDF}_{\mathrm{S}}$ estimated from snow data, and the observed SCA from MODIS in both calibration and validation periods in the Lienz basin. Figure 10 shows a similar figure for Innergschloess. The black dots in Figs. 9 and 10 are the MODIS observed SCA values on days when the observed cloud coverage in the basin was lower than $20 \%$. The similarity of the simulated SCA and observed SCA (just for the days when MODIS was available) is evaluated using RMSE, where $\mathrm{RMSE}_{\mathrm{c}}$ relates to the simulations using calibrated $\mathrm{DDF}_{\mathrm{S}}$ and $\mathrm{RMSE}_{\mathrm{e}}$ relates to the simulations using estimated $\mathrm{DDF}_{\mathrm{S}}$. We determine the $\mathrm{SWE}_{\mathrm{T}}$ threshold by 


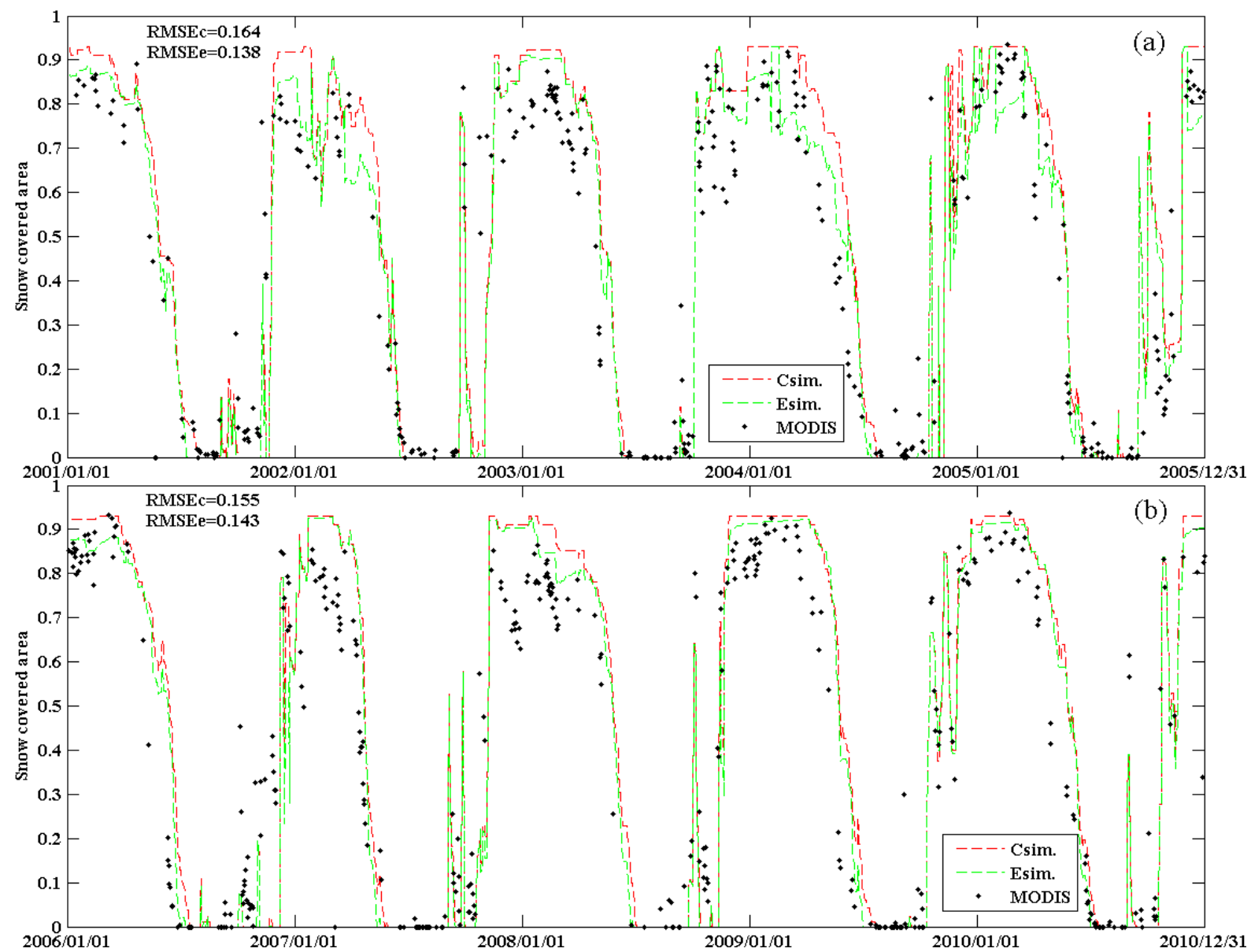

Figure 9. Simulations of the snow covered area (SCA) time series for the Lienz basin $\left(1190 \mathrm{~km}^{2}\right)$. Red lines $\left(C_{\text {sim }}\right)$ represent the SCA simulation using the snowmelt degree-day factor $\left(\mathrm{DDF}_{\mathrm{S}}\right.$ ) calibrated on runoff; green lines (Esim.) represent the SCA simulation using snowmelt degree-day factors estimated from snow data. Black dots are the MODIS observed SCA values. (a) is for the calibration period and (b) is for the validation period. The simulations are evaluated by RMSE $E_{c}$ for the calibrated DDF ${ }_{S}$ and RMSE $_{\mathrm{e}}$ for the estimated DDF .

optimizing the $\mathrm{RMSE}_{\mathrm{c}}$ values in the calibration period in the Lienz basin which resulted in a value of $18 \mathrm{~mm}$. Parajka and Blöschl (2008a) give details on how the threshold can be chosen.

Generally, the simulated snow covered areas by the two $\mathrm{DDF}_{\mathrm{S}}$ sets are similar and both are close to those observed by MODIS in the Lienz basin. The similarity can be attributed to the similar value of estimated and calibrated $\mathrm{DDF}_{S}$ in this basin. It is interesting that the simulation of SCA by estimated $\mathrm{DDF}_{\mathrm{S}}$ (green lines) still has a higher performance as indicated by the lower RMSE $\mathrm{e}_{\mathrm{e}}$ values in both calibration and validation periods. As to the simulation in Innergschloess shown in Fig. 10, the simulated SCA using estimated $\mathrm{DDF}_{\mathrm{S}}$ (green lines) matches the MODIS observed SCA significantly better than that simulated by calibrated $\mathrm{DDF}_{\mathrm{S}}$ (red lines) in both calibration and validation periods. The RMSE $\mathrm{e}_{\mathrm{e}}$ values are approximately 0.07 lower than the $\mathrm{RMSE}_{\mathrm{c}}$ values (Fig. 10). This result suggests that the $\mathrm{DDF}_{\mathrm{S}}$ values estimated from snow data in this basin represent the snowmelt pattern better than the value calibrated on runoff.

Several days with available MODIS data (black dots in Fig. 9) were selected to analyze the snow patterns in Figs. 11-12. The selected days include 29 April, 7 May and 10 June in 2003, and 27 April, 7 and 27 May in 2008. The snow patterns are expressed as the spatial distribution of simulated SWE using calibrated $\mathrm{DDF}_{\mathrm{S}}$ and estimated $\mathrm{DDF}_{\mathrm{S}}$, and the spatial distribution of SCA observed by MODIS. Figures 11 and 12 show the results for the calibration period and validation period, respectively. Subcatchments are covered with snow refers to purple surfaces in Figs. 11 and 12. The intensity of the purple color increases with the increasing of the value of snow coverage (SCA) from MODIS or simulated SWE. The green surface in the two figures refers to areas where SCA value from MODIS or the simulated SWE value is zero, i.e., non-snow covered areas. Generally, a higher simulated SWE value corresponds to a higher MODIS SCA value in that subcatchment. All the three snow patterns 


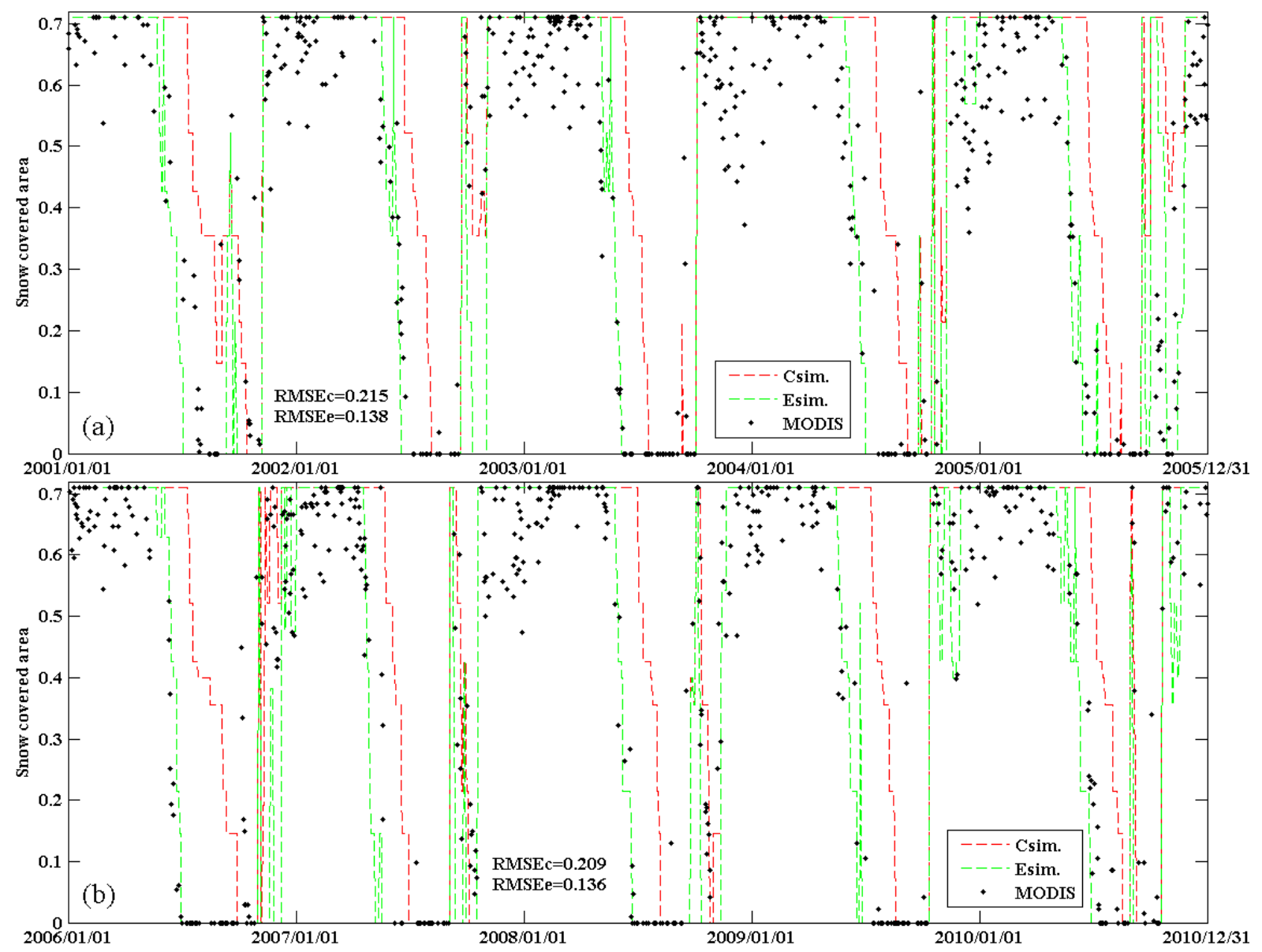

Figure 10. Same as Fig. 9 but for the Innergschloess basin $\left(39 \mathrm{~km}^{2}\right)$.

show a clear snow ablation process from late April to late May. In April, most of the basin area is covered by snow, and the snow water equivalent can be as high as $600-700 \mathrm{~mm}$, while snow cover almost disappears in late May 2003. May is a snowmelt flood month which is also indicated in Fig. 6 by the abrupt increase of discharge in this month. However, there are some differences between the three snow patterns. In the upstream subcatchments, the simulated snow water equivalent using calibrated $\mathrm{DDF}_{\mathrm{S}}$ is higher than that using estimated $\mathrm{DDF}_{\mathrm{S}}$. Correspondingly, the subcatchments are covered with snow simulated by calibrated $\mathrm{DDF}_{\mathrm{S}}$ are more than those observed from MODIS (see Figs. 11 and 12 on 10 June 2003 and 27 May 2008). In the downstream subcatchments, simulated snow covered subcatchments by the two $\mathrm{DDF}_{\mathrm{S}}$ sets are both less than the observed ones (see Figs. 11 and 12 on 29 April 2003 and 7 May 2008). Overall, the similarity between the spatial distribution of snow covered subcatchments simulated using estimated $\mathrm{DDF}_{\mathrm{S}}$ and the spatial distribution observed by MODIS is higher than that simulated using calibrated $\mathrm{DDF}_{\mathrm{S}}$, which can be seen for 7 May, 10 June in 2003, and 27 April and 27 May in 2008. MODIS data were one of the inputs for estimating $\mathrm{DDF}_{S}$, so this result shows the consistency and usefulness of the estimates.

\section{Discussion and conclusions}

This study proposes a method for estimating snowmelt degree-day factor $\left(\mathrm{DDF}_{\mathrm{S}}\right)$ based on MODIS snow cover data and snow depth data. $\mathrm{DDF}_{\mathrm{S}}$ is estimated in each subcatchment of the study basin separately. The spatial distribution of $\mathrm{DDF}_{\mathrm{S}}$ shows a strong correlation with elevation. Subcatchments with high elevations are associated with higher DDF $_{S}$ values, which can be partly attributed to the interactions of climate conditions, topography and vegetation. The comparisons between simulations using $\mathrm{DDF}_{S}$ estimated from snow data and DDF calibrated on runoff in terms of discharge and snow cover patterns show that the estimated $\mathrm{DDF}_{S}$ are indeed more plausible than the calibrated $\mathrm{DDF}_{\mathrm{S}}$. The better performance can be attributed to two advantages of the estimation method: first, using spatially variable snow cover data from MODIS and snow depth data, it is possible to estimate DDFS $_{S}$ in a spatially distributed fashion, while the calibrated $\mathrm{DDF}_{\mathrm{S}}$ are lumped values and therefore spatially uniform. Second, 

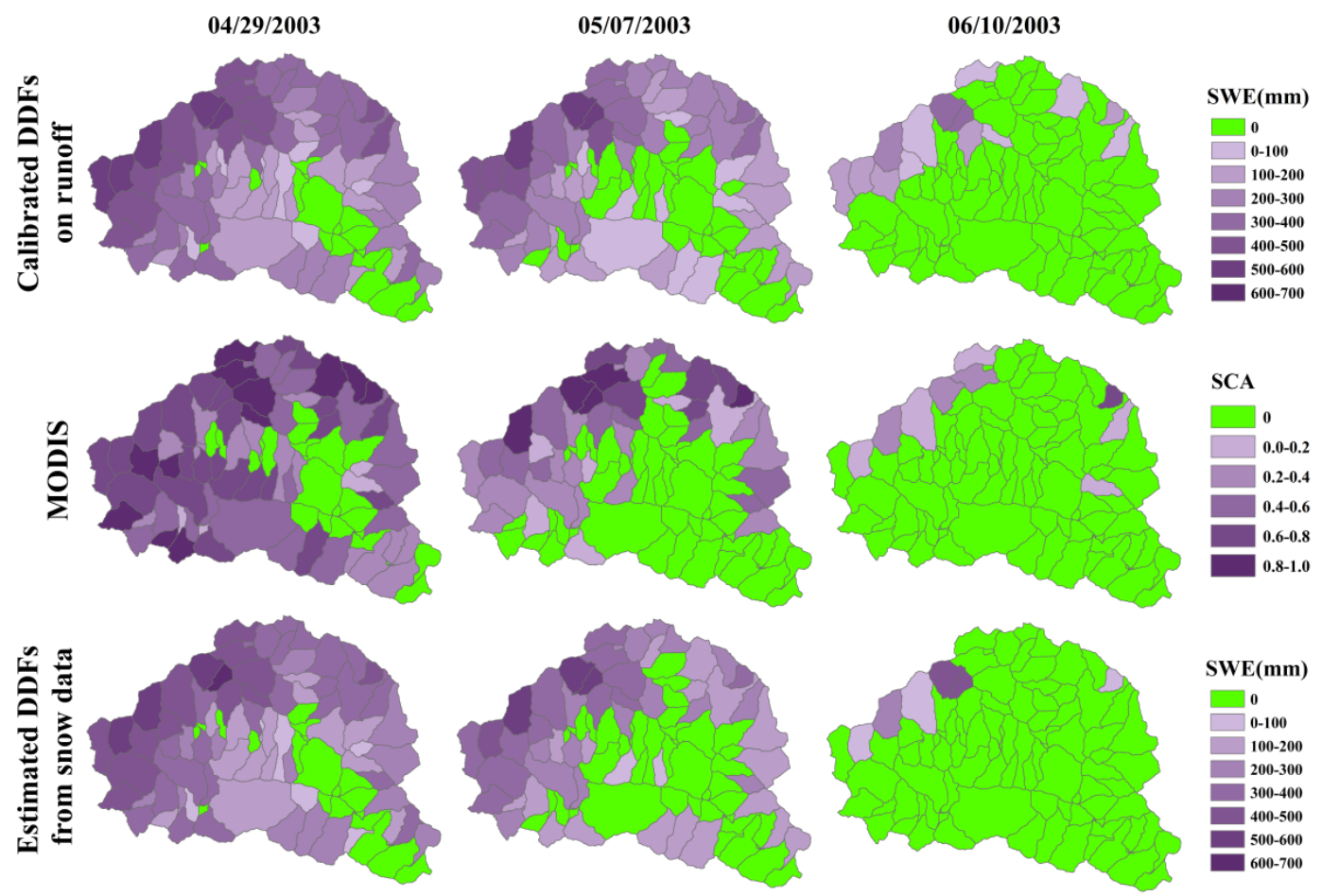

Figure 11. Simulations of snow patterns on 3 days within the calibration period (29 April, 7 May and 10 June 2003). The top row shows simulated snow water equivalent (SWE) using $\mathrm{DDF}_{\mathrm{S}}$ calibrated on runoff, the middle row shows snow covered area (SCA) observed by MODIS, and the bottom row shows simulated snow water equivalent using DDF $_{S}$ estimated from snow data.
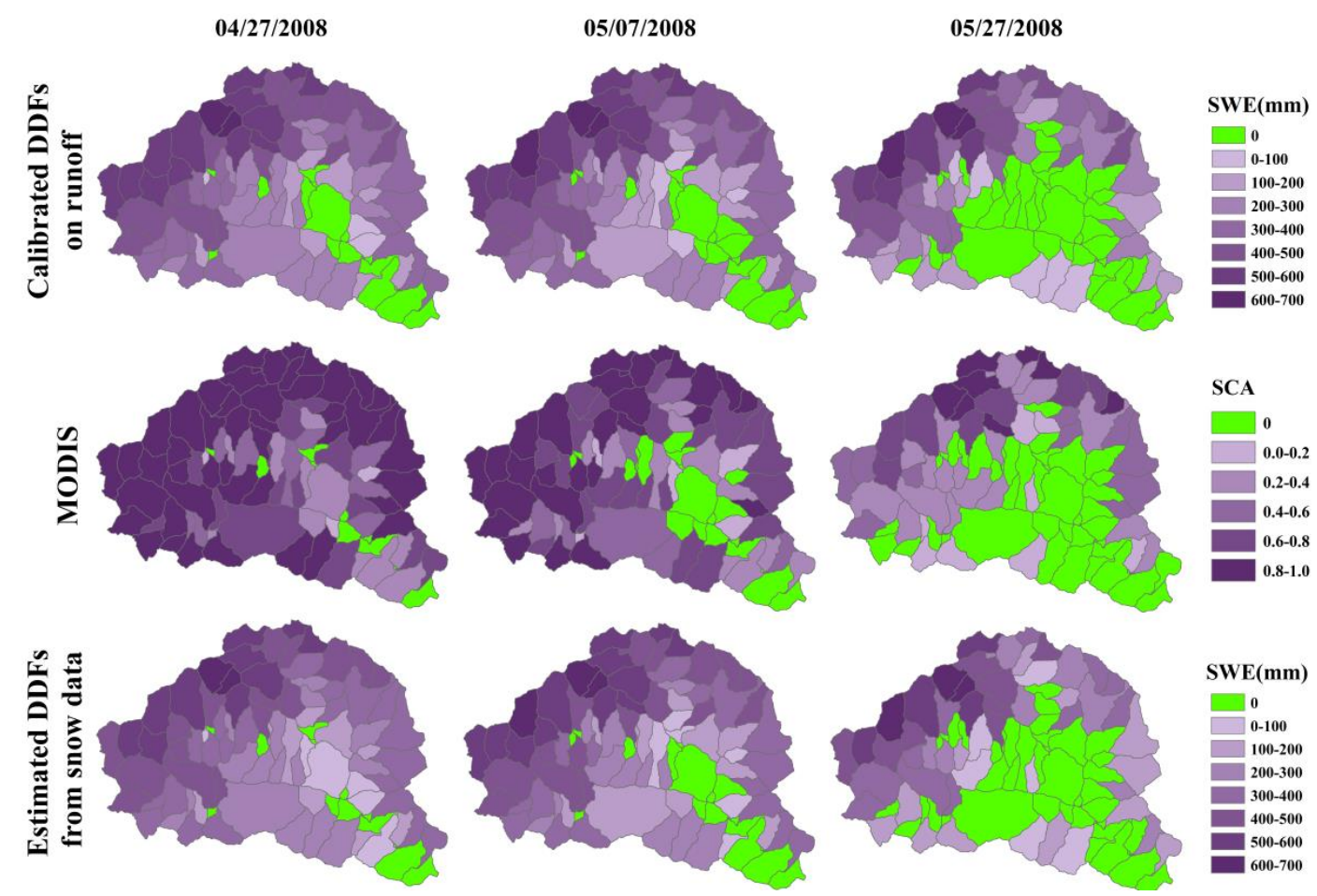

Figure 12. Same as Fig. 11 but for 3 days within the validation period (27 April, 7 and 27 May 2008). 
the values of $\mathrm{DDF}_{\mathrm{S}}$ are estimated directly from observed snow cover data, accounting for snow density, without involving runoff processes. The direct estimation should have a stronger physical basis than the calibration in which the value of $\mathrm{DDF}_{\mathrm{S}}$ is influenced by a number of hydrological processes and the interactions of hydrological model parameters (Merz et al., 2011). However, the modeling improvement when using the spatially distributed $\mathrm{DDF}_{\mathrm{S}}$ should indeed be different for different modeling scales. The modeling scale, i.e., size of fundamental computational unit (subcatchment in this study), can have a significant influence on the simulation, considering the spatial resolution of MODIS data and the spatial density of gauge stations for precipitation and temperature. Adopting different subcatchment sizes in the model could be a potential way to analyze the scale effect on the simulation, which can be an issue for further study.

The estimated values of snow density and $\mathrm{DDF}_{\mathrm{S}}$ are fully consistent with those estimated by Kuusisto (1980), Rango and Martinec (1995), Parajka et al. (2005) and Sturm et al. (2010). The values of snow density estimated in Sturm et al. (2010) in Canada and the US fell into a range of 0.19 to $0.51 \mathrm{~g} \mathrm{~cm}^{-3}$, and the DDFS of snowmelt estimated in Parajka et al. (2005) in Austria ranged from approximately 0.5 to $5.0 \mathrm{~mm}$ day ${ }^{-1}{ }^{\circ} \mathrm{C}^{-1}$. The simulations of snow cover patterns show an obvious snow ablation process from late April to late May in the study basin, which was also indicated by Blöschl et al. (1990). The performance of the runoff simulations in this study is also very reasonable (NSE almost always $>0.8$ ). For example, the runoff simulations of Parajka et al. (2007) in 320 catchments in Austria based on automatic calibration gave NSE mean values of about 0.75 in calibration period and 0.70 in validation period. Considering that high NSE values are relatively easier to be reached in snowmelt affected basins, the performance of the stepwise calibration method should be evaluated in further studies. It is believed that the actual model performance is similar to that of automatic methods, yet the parameter estimates may be more plausible as different parameter groups are estimated separately, which reduces the problem of parameter interdependence in the calibration process.

It should be noted that the estimated values of snow density and $\mathrm{DDF}_{\mathrm{S}}$ are associated with a number of uncertainty sources: the temperature threshold values that determine the occurrence of snowmelt $\left(T_{\mathrm{m}}\right)$ and the transition between liquid and solid precipitation (i.e., $T_{\mathrm{S}}$ and $T_{\mathrm{R}}$ ) and also the spatial interpolation method of the snow depth data. Usually, the value of $T_{\mathrm{m}}$ falls in between the values of $T_{\mathrm{S}}$ and $T_{\mathrm{R}}$ in mountain basins. As long as the temperature is higher than $T_{\mathrm{R}}$, the change of snow water equivalent (SWE) can be attributed to snowmelt alone. When the temperature is lower than $T_{\mathrm{S}}$, basin snow water equivalent will be affected by snowfall alone. The proposed estimation method can be used in mountain basins with variable values of $T_{\mathrm{m}}, T_{\mathrm{S}}$ and $T_{\mathrm{R}}$ in different basins. Reliable snow depth data are important for estimating snow density and $\mathrm{DDF}_{\mathrm{S}}$ well. To obtain the spatial distribution of snow depth, measured data in seven stations in the study area were interpolated here. The interpolation method can play a significant role. Importantly, in this paper we made the assumption that snow density during days of accumulation and ablation is similar. Snow density generally increases with the increasing of snow age. We know that there is in fact a hysteresis in the relationship between snow water equivalent and snow depth (Magand et al., 2014): during accumulation days, snowfall occurs all over the catchment, and the mean snow depth tends to increase quickly and uniformly over the catchment. By contrast, during the ablation days, snowmelt tends to occur in preferential locations due to variability of topography and vegetation in the catchment. The mean snow depth decreases gradually with the reduction of snow water equivalent as snow stays longer at high elevations and small hollows. The effect of this hysteresis on the estimated value of degree-day factor for snowmelt for different subcatchment scales needs further analysis on the basis of detailed snow data. Also the analysis of the sensitivity of the results to other uncertainty sources could be the topic of future work.

Acknowledgements. This study was supported by the National Science Foundation of China (NSFC 51190092, U1202232, 51222901) and the foundation of the State Key Laboratory of Hydroscience and Engineering of Tsinghua University (2014-KY-01). We would like to thank the International Communication Fellowship of Tsinghua University for financial support. We also thank Thomas Nester and Jürgen Komma for their helpful suggestions on the hydrological modeling in Austria, and Magdalena Rogger for providing the hydrogeology data in the study area.

Edited by: V. Andréassian

\section{References}

Andreadis, K. M. and Lettenmaier, D. P.: Assimilating remotely sensed snow observations into a macroscale hydrology model, Adv. Water Resour., 29, 872-886, 2006.

Bach, H., Braun, M., Lampart, G., and Mauser, W.: Use of remote sensing for hydrological parameterisation of Alpine catchments, Hydrol. Earth Syst. Sci., 7, 862-876, doi:10.5194/hess-7-8622003, 2003.

Blöschl, G. and Kirnbauer, R.: An analysis of snow cover patterns in a small Alpine catchment, Hydrol. Process., 6, 99-109, 1992.

Blöschl, G., Kirnbauer, R., and Gutknecht, D.: Modelling snowmelt in a mountainous river basin on an event basis, J. Hydrol., 113, 207-229, 1990.

Blöschl, G., Kirnbauer, R., and Gutknecht, D.: Distributed snowmelt simulations in an Alpine catchment.1. model evaluation on the basis of snow cover patterns, Water Resour. Res., 27, 3171-3179, 1991a. 
Blöschl, G., Gutknecht, D., and Kirnbauer, R.: Distributed snowmelt simulations in an Alpine catchment, 2. Parameter study and model predictions, Water Resour. Res., 27, 3181-3188, 1991b.

Bormann, K. J., Westra, S., Evans, J. P., and McCabe, M. F.: Spatial and temporal variability in seasonal snow density, J. Hydrol., 484, 63-73, 2013.

Bormann, K. J., Evans, J. P., and McCabe, M. F.: Constraining snowmelt in a temperature-index model using simulated snow densities, J. Hydrol., 517, 652-667, doi:10.1016/j.jhydrol.2014.05.073, 2014.

Cazorzi, F. and DallaFontana, G.: Snowmelt modelling by combining air temperature and a distributed radiation index, J. Hydrol., 181, 169-187, 1996.

Daly, S. F., Davis, R., Ochs, E., and Pangburn, T.: An approach to spatially distributed snow modelling of the Sacramento and San Joaquin basins, California, Hydrol. Process., 14, 3257-3271, 2000.

Dery, S. J., Salomonson, V. V., Stieglitz, M., Hall, D. K., and Appel, I.: An approach to using snow areal depletion curves inferred from MODIS and its application to land surface modelling in Alaska, Hydrol. Process., 19, 2755-2774, 2005.

Dunn, S. M. and Colohan, R.: Developing the snow component of a distributed hydrological model: a step-wise approach based on multi-objective analysis, J. Hydrol., 223, 1-16, 1999.

Entekhabi, D., Rodriguez-Iturbe, I., and Castelli, F.: Mutual interaction of soil moisture state and atmospheric processes, J. Hydrol., 184, 3-17, 1996.

Fierz, C., Riber, P., Adams, E. E., Curran, A. R., Fohn, P., Lehning, M., and Pluss, C.: Evaluation of snow-surface energy balance models in alpine terrain, J. Hydrol., 282, 76-94, 2003.

Georgievsky, M. V.: Application of the Snowmelt Runoff model in the Kuban river basin using MODIS satellite images, Environ. Res. Lett., 4, 045017, doi:10.1088/1748-9326/4/4/045017, 2009.

Hall, D. K. and Riggs, G. A.: Accuracy assessment of the MODIS snow products, Hydrol. Process., 21, 1534-1547, 2007.

Hall, D. K., Tait, A. B., Foster, J. L., Chang, A., and Allen, M.: Intercomparison of satellite-derived snow-cover maps, Ann. Glaciol., 31, 369-376, 2000.

Hall, D. K., Riggs, G. A., Salomonson, V. V., DiGirolamo, N. E., and Bayr, K. J.: MODIS snow-cover products, Remote Sens. Environ., 83, 181-194, 2002.

Hall, D. K., Salomonson, V. V., and Riggs, G. A.: MODIS/Terra Snow Cover Daily L3 Global $500 \mathrm{~m}$ Grid, Version 5, National Snow and Ice Data Center, Boulder, Colorado, USA, 2006a.

Hall, D. K., Salomonson, V. V., and Riggs, G. A.: MODIS/Aqua Snow Cover Daily L3 Global $500 \mathrm{~m}$ Grid, Version 5, National Snow and Ice Data Center, Boulder, Colorado, USA, 2006b.

Hamlet, F., Mote, W., Clark, P., and Lettenmaier, P.: Effects of Temperature and Precipitation Variability on Snowpack Trends in the Western United States, J. Climate, 18, 4545-4561, 2005.

He, Z., Tian, F., Hu, H. C., Gupta, H. V., and Hu, H. P.: Diagnostic calibration of a hydrological model in an alpine area, Hydrol. Earth Syst. Sci. Discuss., 11, 1253-1300, doi:10.5194/hessd-111253-2014, 2014.

Hinzman, L. D. and Kane, D. L.: Snow hydrology of a headwater arctic basin - 2. conceptual analysis and computer modeling, Water Resour. Res., 27, 1111-1121, 1991.
Hock, R.: A distributed temperature-index ice- and snowmelt model including potential direct solar radiation, J. Glaciol., 45, 101$111,1999$.

Hock, R.: Temperature index melt modelling in mountain areas, J. Hydrol., 282, 104-115, 2003.

Howard, C.: Revisiting the degree-day method for snowmelt computations - Discussion, Water Resour. Bull., 32, 411-413, 1996.

Immerzeel, W. W., Droogers, P., de Jong, S. M., and Bierkens, M. F. P.: Large-scale monitoring of snow cover and runoff simulation in Himalayan river basins using remote sensing, Remote Sens. Environ., 113, 40-49, 2009.

Jeelani, G., Feddema, J. J., van der Veen, C. J., and Stearns, L.: Role of snow and glacier melt in controlling river hydrology in Liddar watershed (western Himalaya) under current and future climate, Water Resour. Res., 48, W12508, doi:10.1029/2011WR011590, 2012.

Johnson, J. B. and Schaefer, G. L.: The influence of thermal, hydrologic, and snow deformation mechanisms on snow water equivalent pressure sensor accuracy, Hydrol. Process., 16, 3529-3542, 2002.

Kane, D. L., Gieck, R. E., and Hinzman, L. D.: Snowmelt modeling at small Alaskan arctic watershed, J. Hydrol. Eng., 2, 204-210, 1997.

Kirchner, J. W.: Getting the right answers for the right reasons: Linking measurements, analyses, and models to advance the science of hydrology, Water Resour. Res., 42, W03S04, doi:10.1029/2005WR004362, 2006.

Klein, A. G. and Barnett, A. C.: Validation of daily MODIS snow cover maps of the Upper Rio Grande River Basin for the 20002001 snow year, Remote Sens. Environ., 86, 162-176, 2003.

Klok, E. J., Jasper, K., Roelofsma, K. P., Gurtz, J., and Badoux, A.: Distributed hydrological modelling of a heavily glaciated Alpine river basin, Hydrolog. Sci. J., 46, 553-570, 2001.

Kuusisto, E.: On the values and variability of degree-day melting factor in Finland, Nord. Hydrol., 11, 235-242, 1980.

Lang, H. and Braun, L.: On the information content of air temperature in the context of snow melt estimation, in: Hydrology of Mountainous Areas, Proceedings of the Strbske Pleso Symposium 1990, IAHS Publ. no. 190, edited by: Molnar, L., Strbske Pleso, Slovakia, 347-354, 1990.

Langston, G., Bentley, L. R., Hayashi, M., McClymont, A., and Pidlisecky, A.: Internal structure and hydrological functions of an alpine proglacial moraine, Hydrol. Process., 25, 2967-2982, 2011.

Lee, S. W., Klein, A. G., and Over, T. M.: A comparison of MODIS and NOHRSC snow-cover products for simulating streamflow using the Snowmelt Runoff Model, Hydrol. Process., 19, 29512972, 2005.

Li, H. Y., Sivapalan, M., and Tian, F. Q.: Comparative diagnostic analysis of runoff generation processes in Oklahoma DMIP2 basins: The Blue River and the Illinois River, J. Hydrol., 418, 90-109, 2012.

Li, X. G. and Williams, M. W.: Snowmelt runoff modelling in an arid mountain watershed, Tarim Basin, China, Hydrol. Process., 22, 3931-3940, 2008. 
Liu, T., Willems, P., Feng, X. W., Li, Q., Huang, Y., Bao, A. M., Chen, X., Veroustraete, F., and Dong, Q. H.: On the usefulness of remote sensing input data for spatially distributed hydrological modelling: case of the Tarim River basin in China, Hydrol. Process., 26, 335-344, 2012.

Luo, Y., Arnold, J., Liu, S. Y., Wang, X. Y., and Chen, X.: Inclusion of glacier processes for distributed hydrological modeling at basin scale with application to a watershed in Tianshan Mountains, northwest China, J. Hydrol., 477, 72-85, 2013.

Magand, C., Ducharne, A., Moine, N. L., and Gascoin, S.: Introducing Hysteresis in Snow Depletion Curves to Improve the Water Budget of a Land Surface Model in an Alpine Catchment, J. Hydrometeorol., 15, 631-649, 2014.

Marsh, C. B., Pomeroy, J. W., and Spiteri, R. J.: Implications of mountain shading on calculating energy for snowmelt using unstructured triangular meshes, Hydrol. Process., 26, 1767-1778, 2012.

Martinec, J.: The degree-day factor for snowmelt-runoff forecasting, IAHS Publication, No. 51, Surface Waters, in: IUGG General Assembly of Helsinki, Helsinki, Finland, 468-477, 1960.

Maurer, E. P., Rhoads, J. D., Dubayah, R. O., and Lettenmaier, D. P.: Evaluation of the snow-covered area data product from MODIS, Hydrol. Process., 17, 59-71, 2003.

Merz, R., Parajka, J., and Blöschl, G.: Time stability of catchment model parameters: Implications for climate impact analyses, Water Resour. Res., 47, W02531, doi:10.1029/2010WR009505, 2011.

Mou, L., Tian, F., Hu, H., and Sivapalan, M.: Extension of the Representative Elementary Watershed approach for cold regions: constitutive relationships and an application, Hydrol. Earth Syst. Sci., 12, 565-585, doi:10.5194/hess-12-565-2008, 2008.

Musselman, K. N., Molotch, N. P., Margulis, S. A., Kirchner, P. B., and Bales, R. C.: Influence of canopy structure and direct beam solar irradiance on snowmelt rates in a mixed conifer forest, Agr. Forest Meteorol., 161, 46-56, 2012.

Nester, T., Kirnbauer, R., Gutknecht, D., and Blöschl, G.: Climate and catchment controls on the performance of regional flood simulations, J. Hydrol., 402, 340-356, 2011.

Ohmura, A.: Physical basis for the temperature-based melt-index method, J. Appl. Meteorol., 40, 753-761, 2001.

Parajka, J. and Blöschl, G.: The value of MODIS snow cover data in validating and calibrating conceptual hydrologic models, J. Hydrol., 358, 240-258, 2008a.

Parajka, J. and Blöschl, G.: Spatio-temporal combination of MODIS images - potential for snow cover mapping, Water Resour. Res., 44, W03406, doi:10.1029/2007WR006204, 2008b.

Parajka, J. and Blöschl, G.: MODIS-based Snow Cover Products, Validation, and Hydrologic Applications, im: Chapter 9 in Multiscale Hydrological Remote Sensing: Perspectives and Applications, edited by: Chang, N. B. and Hong, Y., CRC Press, Boca Raton, 185-212, 2012.

Parajka, J., Merz, R., and Blöschl, G.: A comparison of regionalisation methods for catchment model parameters, Hydrol. Earth Syst. Sci., 9, 157-171, doi:10.5194/hess-9-157-2005, 2005.

Parajka, J., Merz, R., and Blöschl, G.: Uncertainty and multiple objective calibration in regional water balance modelling: case study in 320 Austrian catchments, Hydrol. Process., 21, 435446, 2007.
Rango, A. and Martinec, J.: Application of a snowmelt-runoff model using Landsat data, Nord. Hydrol., 10, 225-238, 1979.

Rango, A. and Martinec, J.: Revisting the degree-day method for snowmelt computations, Water Resour. Bull., 31, 657-669, 1995.

Singh, P. and Kumar, N.: Determination of snowmelt factor in the Himalayan region, Hydrolog. Sci. J., 41, 301-310, 1996.

Singh, P., Kumar, N., and Arora, M.: Degree-day factors for snow and ice for Dokriani Glacier, Garhwal Himalayas, J. Hydrol., 235, 1-11, 2000.

Sturm, M., Taras, B., Liston, G. E., Derksen, C., Jonas, T., and Lea, J.: Estimating Snow Water Equivalent Using Snow Depth Data and Climate Classes, J. Hydrometeorol., 11, 1380-1394, 2010.

Tekeli, A. E., Akyurek, Z., Sorman, A. A., Sensoy, A., and Sorman, A. U.: Using MODIS snow cover maps in modeling snowmelt runoff process in the eastern part of Turkey, Remote Sens. Environ., 97, 216-230, 2005.

Tian, F., Hu, H., Lei, Z., and Sivapalan, M.: Extension of the Representative Elementary Watershed approach for cold regions via explicit treatment of energy related processes, Hydrol. Earth Syst. Sci., 10, 619-644, doi:10.5194/hess-10-619-2006, 2006.

Tian, F. Q., Hu, H. P., and Lei, Z. D.: Thermodynamic watershed hydrological model: Constitutive relationship, Sci. China Ser. E, 51, 1353-1369, 2008.

Tian, F. Q., Li, H. Y., and Sivapalan, M.: Model diagnostic analysis of seasonal switching of runoff generation mechanisms in the Blue River basin, Oklahoma, J. Hydrol., 418, 136-149, 2012.

Udnaes, H. C., Alfnes, E., and Andreassen, L. M.: Improving runoff modelling using satellite-derived snow covered area?, Nord. Hydrol., 38, 21-32, 2007.

Verbunt, M., Gurtz, J., Jasper, K., Lang, H., Warmerdam, P., and Zappa, M.: The hydrological role of snow and glaciers in alpine river basins and their distributed modeling, J. Hydrol., 282, 3655, 2003.

Viviroli, D., Weingartner, R., and Messerli, B.: Assessing the hydrological significance of the world's mountains, Mount. Res. Develop., 23, 32-40, 2003.

Wang, X. W., Xie, H. J., and Liang, T. G.: Evaluation of MODIS snow cover and cloud mask and its application in Northern Xinjiang, China, Remote Sens. Environ., 112, 1497-1513, 2008.

Western, A. W., Blöschl, G., and Grayson, R. B.: How well do indicator variograms capture the spatial connectivity of soil moisture?, Hydrol. Process., 12, 1851-1868, 1998.

Williams, K. S. and Tarboton, D. G.: The ABC's of snowmelt: a topographically factorized energy component snowmelt model, Hydrol. Process., 13, 1905-1920, 1999.

Zhang, S. Q., Gao, X., Ye, B. S., Zhang, X. W., and Hagemann, S.: A modified monthly degree-day model for evaluating glacier runoff changes in China, Part II: application, Hydrol. Process., 26, 1697-1706, 2012.

Zhao, R. J.: The Xin'anjiang model applied in China, J. Hydrol., 135, 371-381, 1992.

Zhou, X. B., Xie, H. J., and Hendrickx, J.: Statistical evaluation of remotely sensed snow-cover products with constraints from streamflow and SNOTEL measurements, Remote Sens. Environ., 94, 214-231, 2005. 